\title{
Applied Health Physics and Safety Annual Report for 1974
}

\section{OAK RIDGE NATIONAL LABORATORY}

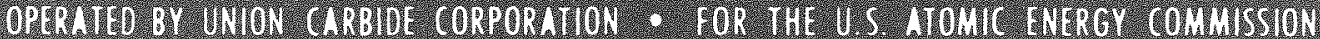




\section{DISCLAIMER}

Portions of this document may be illegible in electronic image products. Images are produced from the best available original document. 
Printed in the United States of America. Available from

National Technical Information Service

U.S. Department of Commerce

5285 Port Royal Road, Springfield, Virginia 22161

Price: Printed Copy $\$ 5.45$; Microfiche $\$ 2.25$

This report was prepared as an account of work sponsored by the United States Government. Neither the United States nor the Energy Research and Development Administration, nor any of their employees, nor any of their contractors, subcontractors, or their employees, makes any warranty, express or implied, or assumes any legal liability or responsibility for the accuracy, completeness or usefulness of any information, apparatus, product or process disclosed, or represents that its use would not infringe privately owned rights. 


\section{ORNL $=5055$ \\ $U C-41$ - Health and Safety}

Contract No. W-7405-eng-26

HEALTH PHYSICS DIVISION

APPLIED HEALTH PHYSICS AND SAFETY ANNUAL REPORT FOR 1974

J. A. Auxier, Director

D. M. Davis, Assistant Director

Thes report was prepared as an account of work sponsored by the United States Covesnment Neither the Unted Stares nor the United States Energy Research and Development Admunstration nor any of their employees, not any of theis contractors, subcontractors or their employees, makes any warranty, express of impled, or assumes any legal labulity of responsibutity for the accuracy completeness or usefulness of any information, apparatus, product of
process disclosed, or represents that tis use would not process disclosed, or represents that its use would not
anfnige privately owned nghts

J. E. Turner, Associate Director

AUGUST 1975

OAK RIDGE NATIONAL LABORATORY

Oak Ridge, Tennessee 37830 operated by UNION CARBIDE CORPORATION

for the ENERGY RESEARCH AND DEVELOPMENT ADMINISTRATION 
0

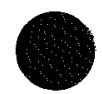


TABLE OF CONTENTS

Page

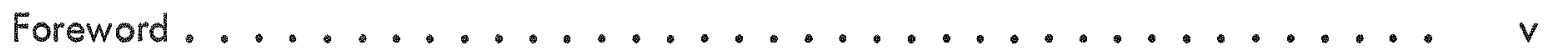

1.0 ORGANIZATION CHART ................. vii

2.0 SUMMARY .............................. 1

3.0 RADIATION MONITORING ..................... 3

3.1 Personnel Monitoring .................... 3

3.2 Health Physics Instrumentation .............. 6

3.3 Developments..................... 7

4.0 ENVIRONS MONITORING .................. 18

4.1 Atmospheric Monitoring ................. 19

4.2 Water Monitoring .................... 21

4.3 Background Measurements ................. 22

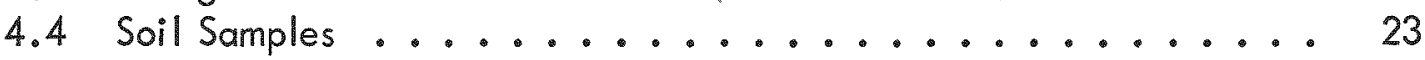

4.5 Environmental Monitoring Samples .............. 23

5.0 RADIATION AND SAFETY SURVEYS .................. 39

5.1 Laboratory Operations Monitoring .............. 39

5.2 Radiation Surveys Made Off-Area ............... 44

5.3 Unusual Occurrences ....................... 45

5.4 Laundry Monitoring ................... 45

6.0 INDUSTRIAL SAFETY AND SPECIAL PROJECTS ........... 48

6.1 Accident Analyses ....................... 48

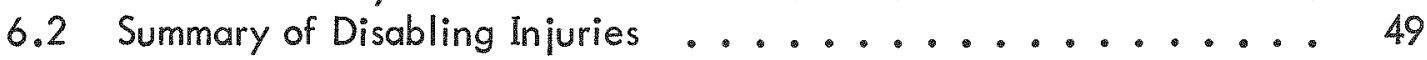

6.3 Safety Awards........................ 50

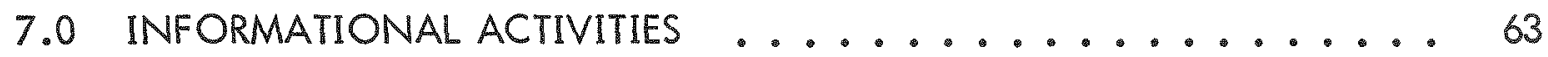

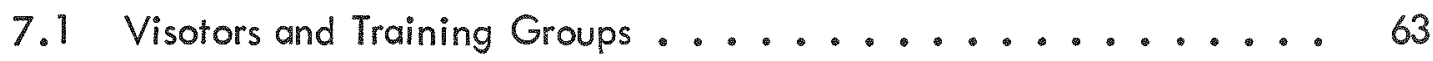

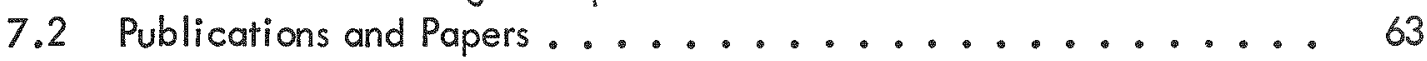


O

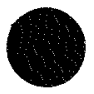




\section{FOREWORD}

This report describes and summarizes the activities of the applied sections of the Health Physics Division, i.e., Radiation Monitoring, Radiation and Safety Surveys, Industrial Safety and Special Projects, and the Environmental Surveillance Department of the Analysis and Assessment of Health Effects Section for calendar year 1974. Projects and activities within the research sections are described in ORNL-4979, Health Physics Division Annual Progress Report, Period Ending July $31,1974$. 
○

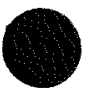


1.0 ORGANIZATION CHART

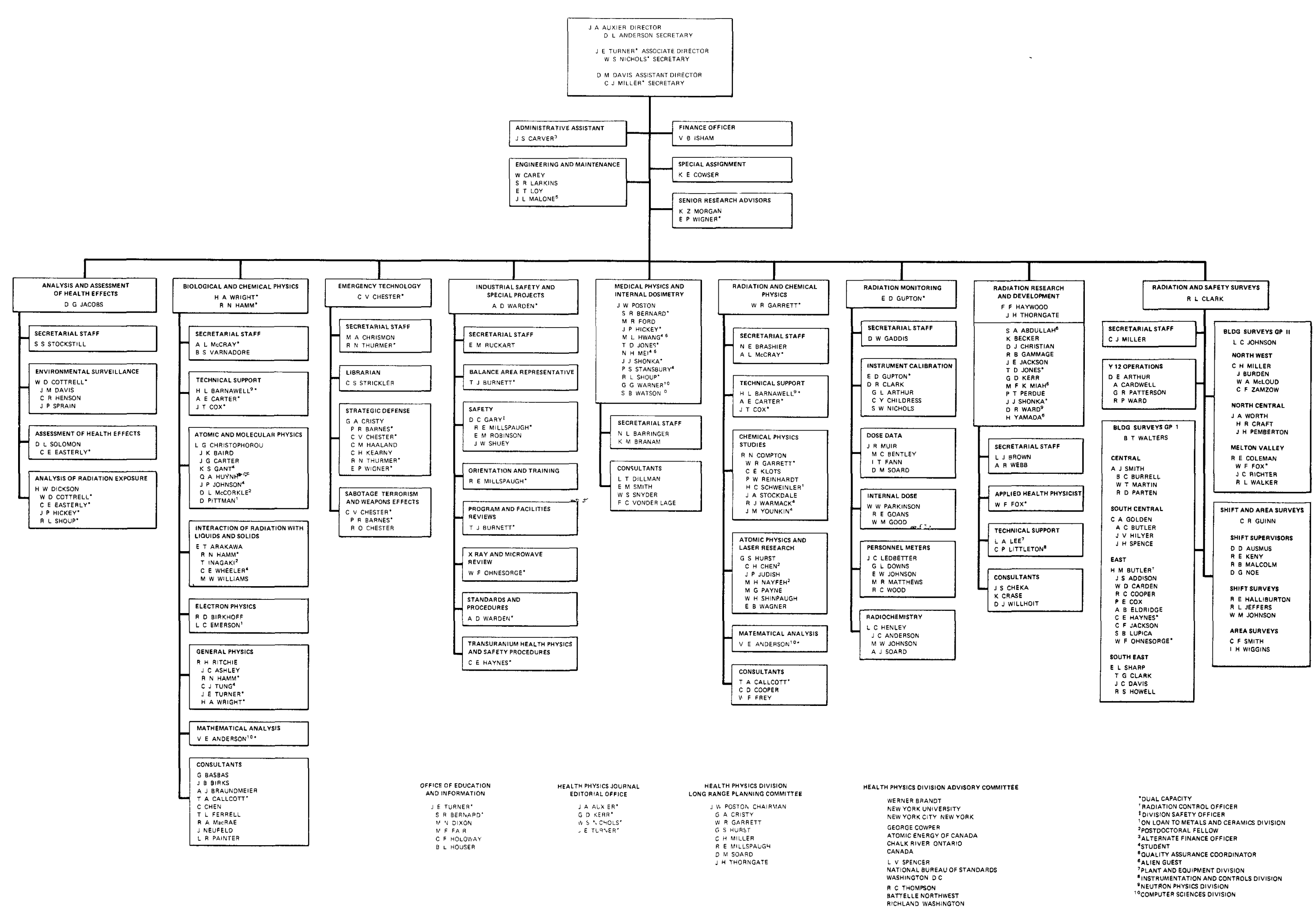




\subsection{SUMMARY}

\section{RADIATION MONITORING}

\section{Personnel Monitoring}

There were no external or internal exposures to personnel which exceeded the standards for radiation protection as defined in ERDA Manual Chapter 0524. Only 41 employees received exposures greater than $1 \mathrm{rem}$. The highest whole body exposure dose equivalent to an employee was $3.58 \mathrm{rem}$. The highest internal exposure was less than one-half of the maximum permissible body burden.

\section{Health Physics Instrumentation}

During 1974, 20 portable instruments were added to the inventory and nine retired. The total number in service on January 1, 1975, was 1,294. There were 22 facility radiation monitoring instruments installed and 21 retired during 1974. The total number in service on January 1, 1975, was 983.

\section{ENVIRONS MONITORING}

\section{Atmospheric Monitoring}

There were no releases of gaseous waste from the Laboratory which were of a level that required an incident report to the ERDA. The average concentration of beta radioactivity in the atmosphere at the perimeter of the ERDA-controlled area was less than one percent of the value applicable to releases to uncontrolled areas.

\section{Water Monitoring}

There were no releases of liquid waste from the Laboratory which were of a level that required an incident report to the ERDA. The quantity of radionuclides of primary concern in the Clinch River averaged less than 0.4 percent of the $M P C_{W}$.

\section{Background Measurements}

The average background level at the PAM and RAM stations during 1974 was $7.5 \mu \mathrm{R} / \mathrm{hr}$, or $0.3 \mu \mathrm{R} / \mathrm{hr}$ less than the average for 1973 .

\section{Soil Samples}

Nine soil samples were collected and analyzed for plutonium and uranium. Plutonium content ranged from $0.9 \times 10^{-8} \mu \mathrm{Ci} / \mathrm{g}$ to $3.4 \times 10^{-8} \mu \mathrm{Ci} / \mathrm{g}$, and the uranium content ranged from $43 \times 10^{-8} \mu \mathrm{Ci} / \mathrm{g}$ to $117 \times 10^{-8} \mu \mathrm{Ci} / \mathrm{g}$. 


\section{RADIATION AND SAFETY SURVEYS}

Laboratory Operations Monitoring

During 1974, the Radiation and Safety Surveys personnel continued to assist the operating groups in keeping the contamination, air concentration, and personnel exposure levels below the established maximum permissible levels. They assisted in reducing or eliminating a number of problems associated with radiation protection at the Laboratory.

\section{Radiation Surveys Made Off-Area}

Several man-months were devoted to off-area surveys. The major portion of this time was in assisting in decontamination efforts at the American Nuclear Corporation.

\section{Unusual Occurrences}

Ten unusual occurrences involving radioactive materials were recorded during 1974. The number reported for 1973 was also 10, and the average number for the past five years (1970-1974) was 10.0.

Laundry Monitoring

Of the 392, 100 articles of wearing apparel monitored during 1974, about 13 percent were found contaminated.

\section{INDUSTRIAL SAFETY AND SPECIAL PRO JECTS}

\section{Accident Analyses}

There were five Disabling Injuries experienced at ORNL in 1974, a frequency rate of 0.81 . The frequency rate for 1973 was 0.33 . The Serious Injury frequency rate for 1974 was 4.9 as compared to a frequency rate of 5.8 for 1973 .

Summary of Disabling Injuries

A total of 315 days were lost or charged for the five Disabling Injuries. No employee suffered any permanent disability.

Safety Awards

No safety awards were achieved in 1974 . 


\subsection{RADIATION MONITORING}

\subsection{Personnel Monitoring}

All persons who enter Laboratory areas where there is a likelihood of exposure to radiation or radioactive materials are monitored for the kinds of exposure they are likely to sustain. External radiation dosimetry is accomplished mainly by means of badge-meters, pocket ion chambers, and hand exposure meters. Internal exposure is determined from bio-assays and in vivo counting.

\subsubsection{Dose Analysis Summary, 1974}

(a) External Exposures - No employee received a whole body radiation dose which exceeded the standards for radiation protection, ERDA Manual Chapter 0524. The maximum whole body dose sustained by an employee was about 3.6 rem or 30 percent of the maximum permissible annual dose. The range of doses to persons using ORNL badge-meters is shown in Table 3.1.1, page 10.

As of December 31, 1974, no employee had a cumulative whole body dose which was greater than the recommended maximum permissible value based on the age proration formula $5(\mathrm{~N}-18)$ (Table 3.1 .2 , page 10). No employee had an average annual exposure rate that exceeded 5 rem per year of employment (Table 3.1.3, page 10). The greatest cumulative dose of whole body radiation received by an employee was approximately $105 \mathrm{rem}$. This dose was accrued over an employment period of about 31 years and represents an average exposure of about 3.4 rem per year.

The greatest cumulative dose to the skin of the whole body received by an employee during 1974 was about 12.6 rem or 42 percent of the maximum permissible annual skin dose of $30 \mathrm{rem}$.

The maximum cumulative hand exposure recorded during 1974 was about 22 rem or 29 percent of the recommended maximum permissible annual dose to the extremities.

The average of the 10 greatest whole body doses to ORNL employees for each of the years 1970 through 1974 is shown in Table 3.1.4, page 11. The maximum indivudual dose for each of those years is shown, also.

(b) Internal Exposures - Two employees sustained inhalation exposure to ${ }^{244} \mathrm{Cm}$. Although both had initial lung depositions in the range 15 to $30 \mathrm{pCi}$, pulmonary clearance was rather rapid and within a few weeks the pulmonary burdens were in the range 0 to $3 \mathrm{pCi}$. Resultant systemic burdens are estimated to be in the range 20 to 40 percent of the MPBB. There was no case of internal exposure during the year for which the radioactive material within the body averaged as much as one-half the maximum permissible organ burden for the year. 


\subsubsection{External Dose Techniques}

(a) Badge Meters - Photobadge meters are issued to all employees and to nonemployees who are authorized to have frequent access to ORNL facilities. Temporary meters are issued to casual visitors.

All badge-meters are equipped with nuclear accident metering devices and betagamma sensitive films. Various complements of TLD's, according to potential for radiation exposure, are included in photobadge meters. NTA films are included, also, in the badges of those who are likely to be exposed to fast neutrons.

Badge-meters of employees are routinely exchanged and processed each calendar quarter, or more frequently if required for exposure control. Meters issued to visitors are processed as may be required for monitoring purposes.

(b) Pocket Meters - Pocket meters (indirect reading, ionization chambers) are made available at all principal points of entry to ORNL premises. A pair of pocket meters is carried for the duration of a work shift by persons who work in an area where the potential for an exposure of $20 \mathrm{mR}$ or more exists during the work shift. Pocket meter pairs are processed each day by Health Physics technicians, and readings of $20 \mathrm{mR}$ or more are reported daily to supervision. Pocket meter readings are used for estimating integrated exposure and as a basis for badge-meter processing during a calendar quarter.

(c) Hand Exposure Meters - Hand exposure meters are TLD-loaded finger rings used to measure hand exposure. Hand exposure meters are issued to persons for use during operations where it is likely that the hand dose may exceed 1 rem during the week. They are issued and collected by Radiation and Safety Surveys personnel who determine the need for this type of monitoring and arrange for a processing schedule.

(d) Metering Résumé - Shown in Table 3.1.5, page 12, are the quantities of personnel metering devices used and processed during 1974. The number of films processed is less than the number issued, because those which are issued for accident dosimetry only are not processed unless there is a likelihood of exposure.

\subsubsection{Internal Dose Techniques}

(a) Bio-Assay - Urine and fecal samples are analyzed for the purpose of making internal dose determinations. The frequency of sampling and the type of radiochemical analysis performed are based upon each specific radioisotope and the exposure potential. Because of the small quantities of radioactive material in most samples, qualitative analyses are not feasible; and only quantitative analyses for predetermined isotopes are performed routinely.

In most cases, bio-assay data require interpretation to determine the dose to the person; computer programs are used for evaluation of extensive data on urinary excre- 
tion of ${ }^{239} \mathrm{Pu}$. An estimate of dose is made for all cases in which it appears that onefourth of a body burden, averaged over a calendar year, may be exceeded.

The analyses performed by the Applied Health Physics and Safety Radiochemical Lab during 1974 are summarized in Table 3.1 .6 , page 13.

(b) Whole Body Counter - The Whole Body Counter (an in vivo gamma spectrometer) may be used for estimating internally deposited quantities of most radionuclides which emit photons.

During the calendar year 1974, there were 278 whole body or thorax counts. Only two cases of detectable activity of significance attributable to exposure at ORNL were found $[\operatorname{Ref} .3 .1 .1(b)]$.

(c) Counting Facility - The Applied Health Physics and Safety counting facility determines radioactivity content of samples submitted by the applied sections. A summary of analyses is in Table 3.1 .7 , page 14.

\section{1 .4 Reports}

Routine reports of personnel monitoring data are prepared and distributed to divisional supervision and to the Applied Health Physics and Safety staff.

(a) Pocket Meter Data - A report is prepared daily of the names, ORNL division, and readings for pocket meter readings which were $20 \mathrm{mR}$ or greater during the previous 24 hours.

A computer-prepared report, which includes all pocket meter data for the previous week and summary data for the calendar quarter, is published and distributed weekly.

(b) External Dosimetry Data - A computer -prepared report, which includes data of recorded skin dose and whole body dose for the previous calendar quarter and totals for the current year, is published and distributed quarterly.

(c) Bio-Assay Data - A computer-prepared report, which includes data of sample status and results for the previous week, is published and distributed weekly. A quarterly and an annual report of results are prepared and distributed.

(d) Whole Body Counter Data - Preliminary results of analysis are reported on a card form soon after counting is done.

A computer-prepared report, which includes data collected during the previous calendar quarters of the calendar year, is published and distributed quarterly. 


\subsubsection{Records}

Permanent records of personnel monitoring data are maintained for each person who is assigned an ORNL photobadge meter.

\subsection{Health Physics Instrumentation}

The Health Physics Division shares with the Instrumentation and Controls Division the responsibility for the selection of electronic radiation monitoring instruments used in the ORNL health physics program. Normally, the Health Physics Division is responsible for determining the need for new instrument types and modifications to existing types, for specifying the health physics requirements, and for approval of the design. The Health Physics Division is also responsible for calibrating all instruments used in the health physics program and is allocated the funds for maintenance of these instruments. Maintenance is performed or cross-ordered by the Instrumentation and Controls Division.

Non-electronic personnel monitoring devices are designed, tested, calibrated, and maintained by Health Physics Division personnel.

\subsubsection{Instrument Inventory}

The electronic instruments used in the health physics program are divided, for convenience in servicing and calibrating, into two classes: the first class includes battery-powered portable instruments; the second class includes the stationary instruments that are AC powered. Portable instruments are assigned and issued to the Radiation and Safety Surveys Complexes. Stationary instruments are the property of the ORNL division which has the monitoring responsibility in the area in which the instrument is located. Table 3.2.1, page 15, lists portable instruments assigned at the end of 1974; Table 3.2.2, page 15, lists stationary instruments at the $X-10$ site in use at the end of 1974 .

Inventory and Service Summaries for health physics instruments are prepared on an IBM 360. These computer-programmed reports enable the Instruments Group to maintain a current inventory on most health physics instrument requirements.

The allocation of stationary health physics monitoring instruments at the $X-10$ site by division is shown in Table 3.2.3, page 16.

\subsubsection{Calibration Facility}

The Health Physics Division maintains a calibration facility for the calibration and maintenance of portable radiation instruments and personnel metering devices. The facility is equipped with calibration sources, remote control devices, and shop space for the use of Instrumentation and Controls Division maintenance personnel. 
Health Physics personnel assign, arrange for maintenance of, calibrate, provide delivery services for, and maintain inventory and servicing data of all portable health physics instruments.

Portable instruments should be serviced (1) whenever repairs are needed, (2) at least once each two months for those which have replacement-type batteries, and (3) at least once each three months for those instruments which have "permanent" (rechargeable) batteries. The number of calibrations of portable instruments for 1974 is shown in Table 3.2.4, page 17.

\subsection{Developments}

\subsubsection{Whole Body Counter}

Since an increasing number of workers at this Laboratory work with insoluble oxides of the transuranic elements, it has been necessary at the Whole Body Counter to develop new instrumental and analytical methods to evaluate lung burdens following accidental inhalation of ${ }^{239} \mathrm{Pu},{ }^{241} \mathrm{Am},{ }^{244} \mathrm{Cm}$ and other isotopes. The lung burden of inhaled actinides is presently determined by external counting of personnel using a standard phoswich detector. Uncertainties in the lung burden can be large even in the best counting geometry. In order to provide a more reliable evaluation of the lung burden of contaminated workers, reasonable, extensive changes have been made in both the equipment and the analytical procedures used to evaluate each count. A more effective utilization of the background-reducing capability of a phoswich system has been made by replacing the previous single-channel time analysis by a much more flexible time-tompulse-height converter. This alternative has provided greater stability, rapid diagnostics, and less dependence of detector efficiency on instrumental parameters.

A general purpose computer unfolding code has also been developed to provide flexible analysis of phoswich spectra containing various isotopes. The code consists of two separate procedures, and normally both algorithms are used to provide independent evaluations of the lung burden. The techniques have been used routinely to detect ${ }^{239} \mathrm{Pu}$ and ${ }^{241} \mathrm{Am}$ in potentially exposed personnel and have been used on special occasions to detect low levels of ${ }^{244} \mathrm{Cm},{ }^{233} \mathrm{U},{ }^{90} \mathrm{Sr},{ }^{153} \mathrm{Gd}$ and other isotopes. Using conservative criteria, it is estimated that 95 percent of the time $9 \mathrm{nCi}$ of ${ }^{239} \mathrm{Pu}$ and $0.06 \mathrm{nCi}$ of ${ }^{241} \mathrm{Am}$ will be detected, while experimentally it is found that $5 \mathrm{nCi}$ of $239 \mathrm{Pu}$ can be detected under good counting conditions in the presence of $0.3 \mathrm{nCi}$ of ${ }^{241} \mathrm{Am}$. Most of the error involved in the calculation of lung burdens for the actinides comes from uncertainties in the value of the chest attenuation factor. Present practice involves an attempt to minimize this error by making an accurate measurement of the tissue thickness external to the rib cage.

In order to measure transuranic lung burdens of less than the maximum permissible level, it is necessary to be able to detect very low counting rates in the presence of 
natural human background $\left({ }^{\circ} \mathrm{K}\right)$ and other interferring species. A better determination of an individual 's ${ }^{\circ} \mathrm{K}$ content has been provided by using a 9 " $\times 9$ " NaI crystal located under the subject and opposite the phoswich detector. The simultaneous monitoring of the $1.46 \mathrm{MeV}$ photopeak of ${ }^{40} \mathrm{~K}$ and the bremsstrahlung $X$-rays has given a more consistent value of body potassium. Use of this method to determine ${ }^{40} \mathrm{~K}$ and use of the unfolding algorithm to strip out interferring isotopes has largely alleviated some of the problems inherent on the use of a phoswich detector and has provided a more sensitive approach to plutonium monitoring.

In this unfolding method, as in others, after examining the net counting rate in a specific region of the spectrum $(12-29 \mathrm{keV}$ for detection of the $17 \mathrm{keV} X$-rays from $238,239 \mathrm{Pu}$ and ${ }^{244} \mathrm{Cm}$ ), it is necessary to decide whether or not various species have, in fact, been detected. Binary hypothesis testing such as this involves two kinds of error: (1) deciding that the contaminant is present when it is not and (2) failing to decide that contamination is present when it is. In line with our attempts to develop new techniques for analysis of phoswich spectra, three simple statistical tests have been developed to formulate a decision strategy which is optimum in the sense of minimizing the long-term risk of error. The analysis allows inclusion of relative risks, thereby putting quantitative policy considerations into what has previously been a qualitative decision process.

\subsubsection{Background Monitoring}

Background exposure rates, except where affected by Laboratory operations, are in the range 5 to $12 \mu \mathrm{R} / \mathrm{hr}$. The rates in some locations vary diurnally and with weather conditions. Exposure rate measurements which may be made from time to time are unlikely to yield the average exposure rate or lead to accurate estimates of integrated exposure.

Several thermoluminescent (TL) materials were evaluated for use in obtaining integrated exposures in the environment. Calcium flouride with dysprosium ( $\mathrm{CaF}_{2}$ :Dy), Harshaw TLD-200, $0.25^{\prime \prime} \times 0.25^{\prime \prime} .0 .035^{\prime \prime}$ ribbon was selected because of high sensitivity and reproducibility, in spite of significant energy dependence and TL signal fading with time.

Adequate energy compensation is obtained with cadmium filters. Correction for fading is obtained by exposing controls to $20 \mathrm{mR}$ at the mid-time of the measurement period, by assuming that the total field exposure occurred at the mid-time of the exposure period, and by using the controls for calibration.

\subsubsection{Personnel Monitoring}

During the year, TLD's (Harshaw TLD-100, $0.125^{\prime \prime} \times 0.125^{\prime \prime} \times 0.035^{\prime \prime}$ ) were used in conjunction with film in the badges of all employees. It was found that the TLD's were more reliable than film in the presence of high relative humidity and temperature. 
There are a few work locations in the Laboratory where there are fluences of thermal and epithermal neutrons which may result in dose equivalents of a few millirem per quarter and which may produce an effect equivalent to 35 - 40 times that many millirem from gamma radiation in the TLD-100. TLD-700, which is relatively insensigive to neutrons, was included in the badges of those who worked in such areas.

In calendar year 1975, the badges of all employees will be equipped with a TLD100, a TLD-700, and a Kodak Type 2 film packet. The TLD-700 will be used for whole body photon dosimetry, the TLD-100 for indication of neutron exposure, and the film for skin dosimetry and information of quality and angle of incidence of exposure.

The badges of persons who are likely to be exposed to neutrons are being equipped with two pairs of TLD-600's and TLD-700's, a dessicated, vapormsealed NTA packet, and a Type $2 \mathrm{film}$. The TLD's, in combination with a cadmium filter, are for dosimetry of neutrons of energy below the cutoff of the NTA film and photons. The NTA film is for dosimetry of higher energy neutrons. 
Table 3.1.1 Dose Data Summary for Laboratory Population Involving Exposure to Whole Body Radiation-1974

\begin{tabular}{l|rr|c|c|c|c|c|c|c|}
\hline \multirow{2}{*}{ Group } & \multicolumn{7}{|c|}{ Number of Rem Doses in Each Range } & \multirow{2}{*}{ Total } \\
\cline { 2 - 9 } & $0-0.1$ & $0.1-1$ & $1-2$ & $2-3$ & $3-4$ & $4-5$ & 5 up & \\
\hline ORNL Employees & 4412 & 504 & 33 & 7 & 1 & 0 & 0 & 4957 \\
$\begin{array}{l}\text { ORNL-Monitored } \\
\text { Non-Employees }\end{array}$ & 60 & 29 & 0 & 0 & 0 & 0 & 0 & 89 \\
TOTAL & 4472 & 533 & 33 & 7 & 1 & 0 & 0 & 5046 \\
\hline
\end{tabular}

Table 3.1.2 Average Rem Per Year Since Age 18-1974

\begin{tabular}{c|c|c|c|c|c}
\hline \multirow{2}{*}{ Group } & \multicolumn{4}{|c|}{ Number of Doses in Each Range } & \multirow{2}{*}{ Total } \\
\cline { 2 - 5 } & $0-2.5$ & $2.5-5.0$ & $5.0-7.5$ & 7.5 up & \\
\hline \multirow{2}{*}{ ORNL Employees } & 4952 & 5 & 0 & 0 & 4957 \\
\hline
\end{tabular}

Table 3.1.3 Average Rem Per Year of Employment at ORNL-1974

\begin{tabular}{c|c|c|c|c|c}
\hline \multirow{2}{*}{ Group } & \multicolumn{4}{|c|}{ Number of Doses in Each Range } & \multirow{2}{*}{ Total } \\
\cline { 2 - 6 } & $0-2.5$ & $2.5-5.0$ & $5.0-7.5$ & 7.5 up & \\
\hline \multirow{2}{*}{ ORNL Employees } & 4945 & 12 & 0 & 0 & 4957 \\
\hline
\end{tabular}


Table 3.1.4 Average of the Ten Highest Whole Body Doses and the Highest Individual Dose by Year

\begin{tabular}{lcc}
\hline Year & $\begin{array}{c}\text { Average of the } \\
\text { Ten Highest Doses } \\
\text { (Rem) }\end{array}$ & $\begin{array}{c}\text { The Highest Dose } \\
\text { (Rem) }\end{array}$ \\
\hline 1970 & 2.79 & 4.04 \\
1971 & 3.41 & 4.95 \\
1972 & 4.18 & 4.88 \\
1973 & 3.12 & 4.63 \\
1974 & 2.34 & 3.58 \\
\hline
\end{tabular}


Table 3.1.5 Personnel Meters Services

$1972 \quad 1973 \quad 1974$

A. Pocket Meter Usage

1. Number of Pairs Used

ORNL

CPFF

$$
79,976 \quad 75,888 \quad 84,864
$$

Total

$\underline{3,796} \quad \underline{6,032} \quad \underline{10,452}$

83,772

81,920

95,316

2. Average Number of Users per Quarter ORNL CPFF

\begin{tabular}{|c|c|c|}
\hline 915 & 753 & 804 \\
\hline 86 & 96 & 160 \\
\hline 1,001 & 849 & 964 \\
\hline
\end{tabular}

B . Meters Processed for Monitoring Data

1. Beta-Gamma Badge-Meter

19,050

19,430

18,490

2. Neutron Badge-Meter

1,250

1,390

550

3. Hand Meter

700

1,400

810 
Table 3.1.6 Radiochemical Lab Analyses-1974

\begin{tabular}{|c|c|c|c|c|c|c|}
\hline Radionuclide & Urine & Feces & Milk & Soil & Water & Controls \\
\hline Plutonium, Alpha & 589 & & & 17 & & 95 \\
\hline Transplutonium, Alpha & 466 & 29 & & 8 & 128 & 70 \\
\hline Uranium, Alpha & 214 & 4 & & 13 & & 10 \\
\hline Strontium, Beta & 308 & & 468 & 4 & 12 & 30 \\
\hline Cesium-137 & 55 & & & & & 10 \\
\hline Tritium & 136 & & & & 140 & 35 \\
\hline lodine-131 & & & 468 & & & \\
\hline Other & 93 & & & & & 5 \\
\hline TOTALS & 1861 & 33 & 936 & 42 & 280 & 255 \\
\hline
\end{tabular}


Table 3.1.7 Counting Facility Analyses-1974

\begin{tabular}{l|c|c|c|c}
\hline \multirow{2}{*}{ Types of Samples } & \multicolumn{3}{|c|}{ Number of Samples } & $\begin{array}{r}\text { Unit } \\
\text { Total }\end{array}$ \\
\cline { 2 - 4 } & Alpha & Beta & Gamma & \\
\hline Facility Monitoring & & & 100,418 \\
Smears & 49,556 & 50,862 & & 26,826 \\
Air Filters & 14,348 & 12,478 & & \\
& & & & \\
Environs Monitoring & & & 250 & 6,210 \\
Air Filters & 2,980 & 2,980 & 3,120 \\
Fallout & 3,020 & 100 & 734 \\
Rainwater & 734 & & 156 \\
Surface Water & & 156 & & 468 \\
Milk & & 468 & \\
\hline
\end{tabular}


Table 3.2.1 Portable Instrument Inventory -1974

\begin{tabular}{lccc}
\hline Instrument Type & $\begin{array}{c}\text { Instruments } \\
\text { Added } \\
1974\end{array}$ & $\begin{array}{c}\text { Instruments } \\
\text { Retired } \\
1974\end{array}$ & $\begin{array}{c}\text { In } \\
\text { Service } \\
\text { Jan. 1, 1975 }\end{array}$ \\
\hline G-M Survey Meter & 0 & 9 & 452 \\
Cutie Pie & 0 & 0 & 424 \\
Alpha Survey Meter & 20 & 0 & 284 \\
Neutron Survey Meter & 0 & 0 & 104 \\
Miscellaneous & 0 & 0 & 30 \\
TOTAL & 20 & 9 & 1,294 \\
\hline
\end{tabular}

Table 3.2.2 Inventory of Facility Radiation Monitoring Instruments for the Year-1974

\begin{tabular}{lccc}
\hline $\begin{array}{c}\text { Instrument } \\
\text { Type }\end{array}$ & $\begin{array}{c}\text { Installed } \\
\text { During 1974 }\end{array}$ & $\begin{array}{c}\text { Retired } \\
\text { During 1974 }\end{array}$ & $\begin{array}{c}\text { Total } \\
\text { Jan. 1, 1975 }\end{array}$ \\
\hline Air Monitor, Alpha & 6 & 1 & 103 \\
Air Monitor, Beta & 2 & 2 & 175 \\
Lab Monitor, Alpha & 1 & 1 & 168 \\
Lab Monitor, Beta & 2 & 2 & 207 \\
Monitron & 3 & 4 & 211 \\
Other & 8 & 11 & 119 \\
TOTAL & 22 & 21 & 983 \\
\hline
\end{tabular}


Table 3.2.3 Health Physics Facility Monitoring Instruments

Divisional Allocation at $X-10$ Site -1974

\begin{tabular}{lrrrrrrr}
\hline \multicolumn{1}{c}{ ORNL Division } & $\begin{array}{c}\alpha \text { Air } \\
\text { Monitor }\end{array}$ & $\begin{array}{c}\beta \text { Air } \\
\text { Monitor }\end{array}$ & $\begin{array}{c}\alpha \text { Lab } \\
\text { Monitor }\end{array}$ & $\begin{array}{c}\beta \text { Lab } \\
\text { Monitor }\end{array}$ & Monitron & Other & Total \\
\hline Analytical Chemistry & 6 & 13 & 16 & 15 & 15 & 6 & 71 \\
Chemical Technology & 48 & 48 & 63 & 32 & 41 & 34 & 266 \\
Chemistry & 9 & 9 & 19 & 24 & 19 & 8 & 88 \\
Metals and Ceramics & 11 & 6 & 14 & 4 & 5 & 9 & 49 \\
Isotopes & 18 & 28 & 24 & 45 & 52 & 19 & 186 \\
Operations & 2 & 51 & 8 & 29 & 20 & 15 & 164 \\
All Others & 9 & 20 & 24 & 58 & 211 & 119 & 983 \\
TOTAL & 103 & 175 & 168 & 207 & 159 \\
\hline
\end{tabular}


Table 3.2.4 Calibrations Facility Résumé-1974

\begin{tabular}{lrr}
\hline & 1973 & 1974 \\
\hline Beta-Gamma & 2,932 & 2,629 \\
Neutron & 389 & 337 \\
Alpha & 798 & 879 \\
Personal Dosimeters & 3,122 & 3,190 \\
Badge Dosimetry Components & 15,650 & 16,208 \\
\hline
\end{tabular}




\subsection{ENVIRONS MONITORING}

The Health Physics Division monitors for airborne radioactivity in the East Tennessee area by the use of three separate monitoring networks. The local air monitoring (LAM) network consists of 22 stations which are positioned in the immediate vicinity of ORNL operational activities; the perimeter air monitoring (PAM) network consists of nine stations which are located near the perimeter of the ERDA-controlled area; and the remote air monitoring (RAM) network consists of eight stations which are located outside the ERDA-controlled area at distances of from 12 to 75 miles from ORNL. ${ }^{2}$ The monitoring networks provide for the collection of (1) airborne radioactivity by air filtration techniques, (2) radioparticulate fallout material by impingement on gummed paper trays, (3) rainwater for measurement of fallout occurring as rainout, and (4) atmospheric levels of radioiodine using charcoal cartridges.

Low-level radioactive liquid wastes originating from ORNL operations are discharged, after preliminary treatment, to White Oak Creek, which is a small tributary of the Clinch River. The radioactive content of White Oak Creek discharge is determined at White Oak Dam which is the last control point along the stream prior to entry of White Oak Creek waters into Clinch River waters. Water samples are collected also at a number of locations along the Clinch River, beginning at a point above the entry of waste into the River via White Oak Creek and ending at Center's Ferry (near Kingston, Tennessee) about 16 miles downstream from the confluence of White Oak Creek and the Clinch River. Water samples are analyzed for gross radioactivity and for specific radionuclides present in detectable quantities. The concentration of each nuclide detected is compared with its respective $M P C_{W}$ value, as specified by ERDA Manual Chapter 0524, and the resulting fractions summed to arrive at the percent $M P C_{W}$ in the Clinch River.

Samples of ORNL potable water are collected daily, composited and stored. At the end of each quarter these composites are analyzed radiochemically for ${ }^{90} \mathrm{Sr}$ content and are assayed for long-lived gamma-emitting radionuclides by gamma spectrometry.

Raw milk samples are collected at 12 sampling stations located within a radius of 50 miles from ORNL. Samples are taken on a weekly basis from eight stations which are located outside the ERDA-controlled area within a 12-mile radius of ORNL. Samples are collected every five weeks from the four remaining stations, all of which are located outside the 12-mile radius up to distances of about 50 miles. The purpose of the milk sampling program is twofold: first, samples collected in the immediate vicinity of ORNL provide data by which one may evaluate the possible effect of waste releases originating from ORNL operations; second, samples collected remote to the immediate vicinity of ORNL provide background data which are essential in

${ }^{1}$ For maps showing location of station, see ORNL-4423, Applied Health Physics and Safety Annual Report for 1968. 
establishing a proper index from which releases of radioactive materials originating from Oak Ridge operations may be evaluated.

Background gamma radiation measurements are made at a number of locations in the East Tennessee area. These measurements are taken with thermoluminescent detectors at a height of four feet above the surface of the ground.

Fish from the Clinch River are sampled during the spring and summer and analyzed for their radioactive content. The radionuclide concentrations in fish are related quantitatively to potential human intake of radioactivity through consumption of fish.

\subsection{Atmospheric Monitoring}

\subsubsection{Air Concentrations}

The average concentrations of beta radioactivity in the atmosphere, as measured with filters from the LAM, PAM, and RAM networks during 1974, were as follows:

$\begin{array}{lc}\text { Network } & \text { Concentration }(\mu \mathrm{Ci} / \mathrm{cc}) \\ \text { LAM } & 10.0 \times 10^{-14} \\ \text { PAM } & 8.4 \times 10^{-14} \\ \text { RAM } & 8.4 \times 10^{-14}\end{array}$

The LAM network value of $10 \times 10^{-14} \mu \mathrm{Ci} / \mathrm{cc}$ is less than 0.01 percent of the MPCU ${ }^{2}$ based on occupational exposure of $3 \times 10^{-9} \mu \mathrm{Ci} / \mathrm{cC}$. Both the PAM and RAM network values represent $<0.1$ percent of the $\mathrm{MPCU}_{\mathrm{a}}$ of $1 \times 10^{-10} \mathrm{\mu Ci} / \mathrm{cc}$ applicable to releases to uncontrolled areas. A tabulation of data for each station in each network is given in Table 4.1.1, page 24. The weekly values for each network are illustrated in Table 4.1.2. page 25.

The values measured for 1974 are higher than those for 1973 by a factor of $\sim 4$ for both the PAM and RAM networks and by a factor of $\sim 2$ for the LAM network. This increase in gross beta concentrations was measured at all stations in all three systems during the period March, 1974, through August, 1974. Gamma spectrometric analysis of filter samples during this period indicated the activity to be due predominantly to ${ }^{103} \mathrm{Ru},{ }^{141} \mathrm{Ce}$, and $95 \mathrm{Zr}-95 \mathrm{Nb}$.

${ }^{2}$ The MPCU $a$ is defined as the maximum permissible concentration for an unknown mixture of radioisotopes in air. ERDA Manual Chapter 0524, Appendix, Annex 1, gives exposure values applicable to various mixtures of radionuclides and establishes guidelines for deriving the $M P C U_{a}$. 
An increase in the concentrations of particulate radioactivity in air was detected at locations in both the eastern and western United States during the same period by the air monitoring network operated by the National Environmental Research CenterLas Vegas (NERC-LV) and by the Environmental Radiation Ambient Monitoring System (ERAMS). ${ }^{3}$ Gamma spectrometric analysis of samples collected in May by NERC-LV identified the radionuclides ${ }^{106} \mathrm{Ru},{ }^{141} \mathrm{C} i$, and ${ }^{95} \mathrm{Zr}$; and their presence was attributed to seasonal variations in world fallout. ${ }^{4}$

\subsubsection{Fallout (Gummed Paper Technique)}

An increase in the number of particles observed by autoradiography during 1974 corresponds to the increase in concentration of particulate radioactivity observed from filter paper data during 1974. The average activity and number of particles per square foot are shown in Table 4.1.3, page 26.

\subsubsection{Rainout (Gross Analysis of Rainwater)}

The average concentration of radioactivity in rainwater collected from the three networks during 1974 was as follows:

$\begin{array}{lc}\text { Network } & \text { Concentration }(\mu \mathrm{Ci} / \mathrm{cc}) \\ \text { LAM } & 3.8 \times 10^{-8} \\ \text { PAM } & 3.8 \times 10^{-8} \\ \text { RAM } & 5.9 \times 10^{-8}\end{array}$

The average concentration measured at each station within each network is presented in Table 4.1.4, page 27. The average concentration for each network for each week is given in Table 4.1.5, page 28.

\subsubsection{Atmospheric Radioiodine (Charcoal Cartridge Technique)}

Atmospheric iodine sampled at the perimeter stations averaged $0.8 \times 10^{-14} \mu \mathrm{Ci} / \mathrm{cc}$ during 1974. This average represents about 0.01 percent of the maximum permissible concentration of $1 \times 10^{-10} \mu \mathrm{Ci} / \mathrm{cc}$ applicable to inhalation of ${ }^{131}$ I released to uncontrolled areas. The maximum concentration observed at any one station for one week was $4.0 \times 10^{-14} \mu \mathrm{Ci} / \mathrm{cc}$ at PAM 38, the perimeter station located east of the EGCR site.

${ }^{3}$ Radiation Data and Reports 15 (6-12), June 1974 to January 1975.

${ }^{4}$ Radiation Data and Reports 15 (10), October 1974. 
The average radioiodine concentration at the local stations was $2.9 \times 10^{-14}$ $\mu \mathrm{Ci} / \mathrm{cc}$. This concentration is less than 0.01 percent of the maximum permissible concentration for inhalation by occupational personnel. The maximum concentration at any one station for one week was $17 \times 10^{-14} \mu \mathrm{Ci} / \mathrm{cc}$ at LAM 9 located north of Bethel Valley Road.

Table 4.1.6, page 29, presents the ${ }^{131}$ I weekly average concentration data for both the local area (LAM) and the perimeter area (PAM) air monitoring networks.

\subsubsection{Milk Analysis}

The quarterly average and maximum concentrations of ${ }^{131} \mathrm{I}$ and ${ }^{90} \mathrm{Sr}$ in raw milk are given in Tables 4.1.7 and 4.1.8, page 30. If one assumes the average intake of milk per individual to be one liter per day, the average concentrations of ${ }^{131}$ I in milk collected near ORNL and in milk collected more remotely from ORNL are within FRC Range I. The average concentrations of ${ }^{90} \mathrm{Sr}$ in milk from both the immediate and remote environs of ORNL are also within FRC Range I.

The concentration of ${ }^{90} \mathrm{Sr}$ in milk is different for different locations; part of the variation has been found to result from differences in farming methods at different farms. Pastureland that is not fertilized and is overgrazed (a not too uncommon practice in this area) apparently results in a higher than normal concentration of ${ }^{90} \mathrm{Sr}$ in milk from cows pastured on this land.

\subsubsection{ORNL Stack Releases}

The ${ }^{131}$ I releases from ORNL stacks are summarized in Table 4.1.9, page 31.

\subsection{Water Monitoring}

\subsubsection{White Oak Lake Waters}

Yearly discharges of specific radionuclides to the Clinch River, 1968 through 1974, are shown in Table 4.2.1, page 32.

The calculated average concentrations of the significant radionuclides in the Clinch River at Clinch River Mile (CRM) 20.8 (the point of entry of White Oak Creek into the River) are presented in Table 4.2.2, page 33. The percent $M P C_{w}$ did not exceed one percent for any month during 1974 (Table 4.2.3, page 34).

\subsubsection{Clinch River Water}

The measured average concentrations and the percent of $M P C_{W}$ of radionuclides in the Clinch River at Melton Hill Dam (CRM 23.1), about three miles upstream, at 
Gallaher (CRM 14.5), about six miles downstream, and at Center's Ferry (CRM 4.5), about 16 miles downstream from the entry of White Oak Creek, are given in Table 4.2 .2 , page 33 .

\subsubsection{Potable Water} follows:

The average concentrations of ${ }^{\circ} \mathrm{Sr}$ in potable water at ORNL during 1974 were as

\begin{tabular}{cc} 
Quarter Number & Concentration of ${ }^{90} \mathrm{Sr}(\mu \mathrm{Ci} / \mathrm{ml})$ \\
\hline 1 & $9.1 \times 10^{-10}$ \\
2 & $1.4 \times 10^{-10}$ \\
3 & $1.8 \times 10^{-10}$ \\
4 & $1.4 \times 10^{-10}$ \\
Average for year & $3.4 \times 10^{-10}$
\end{tabular}

The average value of $3.4 \times 10^{-10}$ represents 0.11 percent of the $M P C_{W}$ for drinking water applicable to individuals in the general population.

\subsubsection{Radionuclides in Clinch River Fish}

Two species of fish, white crappie and carp, were sampled from the Clinch River during the spring and summer of 1974. The fish were prepared for radiochemical analysis in a manner analogous to human utilization. Ten fish of each species were composited and the samples were analyzed, by gamma spectrometry and radiochemical techniques, for the critical radionuclides contributing significantly to the potential radiation dose to man. The data are tabulated in $\mathrm{pCi} / \mathrm{kg}$ of wet weight (Table 4.2.4, page 35) for each radionuclide of significance. An estimate of man's intake of radionuclides from eating the fish is made by assuming an annual rate of fish consumption of 37 pounds. An estimated percentage of maximum permissible intake is calculated by assuming a maximum permissible intake of fish to be comparable to a daily intake of 2.2 liters of water containing the $M P C_{w}$ of these radionuclides for a period of one year.

\subsection{Background Measurements}

Background measurements were made at the PAM and RAM stations. The average background level during 1974, as measured at these stations, was $7.5 \mu \mathrm{R} / \mathrm{hr}$. Average background readings for each station are presented in Table 4.3.1, page 36. 


\subsection{Soil Samples}

Soil samples are collected annually from near the PAM stations. Nine samples, approximately three inches in diameter and one centimeter thick, are collected in a one-square-meter area at each location, composited, and analyzed radiochemically for uranium and plutonium content to determine background information for future comparison in the event of an accidental release. Data on uranium and plutonium concentrations in soil are given in Table 4.4.1, page 37.

\subsection{Environmental Monitoring Samples}

A listing of environmental monitoring samples processed by type sample, type of analyses, and number of samples is given in Table 4.5.1, page 38. 
Table 4.1.1 Concentration of Beta Radioactivity in Air - 1974

(Filter Paper Data-Weekly Average)

\begin{tabular}{|c|c|c|}
\hline $\begin{array}{l}\text { Station } \\
\text { Number }\end{array}$ & Location & $\begin{array}{l}\text { Long-Lived Acriv } \\
\qquad 10^{-14} \mu \mathrm{Ci} / c c\end{array}$ \\
\hline \multicolumn{3}{|c|}{ Laboratory Area } \\
\hline $\mathrm{HP}-1$ & S 3587 & 9.8 \\
\hline$H P=2$ & NE 3025 & 9.9 \\
\hline $\mathrm{HP}-3$ & SW 1000 & 9.2 \\
\hline$H P-4$ & W Settling Basin & 9.5 \\
\hline$H P-5$ & E 2506 & 14. \\
\hline$H P-6$ & SW 3027 & 10. \\
\hline $\mathrm{HP}-7$ & W 7001 & 8.2 \\
\hline HP-8 & Rock Quarry & 9.2 \\
\hline$H P=9$ & N Bethel Valley Road & 8.8 \\
\hline $\mathrm{HP}-10$ & W 2075 & 9.8 \\
\hline $\mathrm{HP}-16$ & E 4500 & 11. \\
\hline $\mathrm{HP}-20$ & HFIR & 10. \\
\hline Average & & 10. \\
\hline \multicolumn{3}{|c|}{ Perimeter Area } \\
\hline HP-31 & Kerr Hollow Gate & 8.7 \\
\hline HP-32 & Midway Gate & 9.2 \\
\hline HP-33 & Gallaher Gate & 6.9 \\
\hline$H P-34$ & White Oak Dam & 8.8 \\
\hline $\mathrm{HP}-35$ & Blair Gate & 9.5 \\
\hline $\mathrm{HP}-36$ & Turnpike Gate & 10 \\
\hline HP-37 & Hickory Creek Bend & 6.6 \\
\hline $\mathrm{HP}-38$ & E EGCR & 7.0 \\
\hline $\mathrm{HP}-39$ & Townsite & 8.8 \\
\hline Average & & 8.4 \\
\hline \multicolumn{3}{|c|}{ Remote Area } \\
\hline$H P-51$ & Norris Dam & 7.4 \\
\hline $\mathrm{HP}-52$ & Loudoun Dam & 7.0 \\
\hline$H P=53$ & Douglas Dam & 8.1 \\
\hline HP-54 & Cherokee Dam & 10. \\
\hline$H P-55$ & Watts Bar Dam & 9.1 \\
\hline $\mathrm{HP}-56$ & Great Falls Dam & 8.6 \\
\hline HP-57 & Dale Hollow Dam & 9.1 \\
\hline$H P-58$ & Knoxville & 7.5 \\
\hline Average & & 8.4 \\
\hline
\end{tabular}


Table 4.1.2 Concentration of Beta Radioactivity in Air as Determined from Filter Paper Data-1974

(System Average - by Weeks)

\begin{tabular}{|c|c|c|c|c|c|c|c|}
\hline \multirow{2}{*}{$\begin{array}{l}\text { Week } \\
\text { Number }\end{array}$} & \multicolumn{3}{|c|}{ Units of $10^{-14} \mu \mathrm{Ci} / \mathrm{cc}$} & \multirow{2}{*}{$\begin{array}{l}\text { Week } \\
\text { Number }\end{array}$} & \multicolumn{3}{|c|}{ Units of $10^{-14} \mu \mathrm{Ci} / \mathrm{cc}$} \\
\hline & LAM's & PAM's & RAM's & & LAM's & PAM's & RAM's \\
\hline 1 & 2.1 & 1.9 & 1.9 & 29 & 17. & 13. & 13. \\
\hline 2 & 4.5 & 2.9 & 3.2 & 30 & 12. & 10. & 10 \\
\hline 3 & 3.0 & 2.6 & 2.4 & 31 & 13. & 9.1 & 11. \\
\hline 4 & 4.3 & 3.4 & 3.5 & 32 & 11. & 7.6 & 8.8 \\
\hline 5 & 8.2 & 8.2 & 7.7 & 33 & 15. & 9.7 & 10 \\
\hline 6 & 4.5 & 5.1 & 4.8 & 34 & 11. & 5.0 & 5.8 \\
\hline 7 & 7.9 & 8.4 & 6.4 & 35 & 7.1 & 4.6 & 5.8 \\
\hline 8 & 6.1 & 6.4 & 7.0 & 36 & 2.7 & 2.0 & 2.4 \\
\hline 9 & 6.8 & 9.5 & 8.6 & 37 & 3.9 & 3.0 & 2.9 \\
\hline 10 & 13. & 16. & 12. & 38 & 5.4 & 3.7 & 4.5 \\
\hline 11 & 11. & 12. & 8.5 & 39 & 5.6 & 3.2 & 3.0 \\
\hline 12 & 9.5 & 10. & 8.9 & 40 & 3.9 & 3.2 & 2.7 \\
\hline 13 & 13. & 12. & 13. & 41 & 6.1 & 4.7 & 4.5 \\
\hline 14 & 12. & 12. & 9.9 & 42 & 3.0 & 1.7 & 1.9 \\
\hline 15 & 15. & 16. & 15. & 43 & 5.3 & 3.3 & 3.8 \\
\hline 16 & 19. & 19. & 19. & 44 & 2.9 & 2.1 & 1.7 \\
\hline 17 & 28. & 26. & 27. & 45 & 3.9 & 2.5 & 2.7 \\
\hline 18 & 20. & 15. & 19. & 46 & 4.3 & 1.9 & 2.4 \\
\hline 19 & 16. & 13 & 17. & 47 & 2.4 & 1.4 & 1.7 \\
\hline 20 & 17. & 15. & 14. & 48 & 3.7 & 2.3 & 2.2 \\
\hline 21 & 22. & 18. & 17. & 49 & 7.1 & 5.6 & 5.7 \\
\hline 22 & 13. & 14. & 16. & 50 & 7.2 & 4.9 & 5.7 \\
\hline 23 & 9.6 & 11. & 10. & 51 & 7.5 & 5.6 & 5.5 \\
\hline 24 & 23. & 18. & 18. & 52 & 5.7 & 4.4 & 4.6 \\
\hline 25 & 15. & 13. & 14. & & & & \\
\hline 26 & 15. & 15. & 11. & & & & \\
\hline 27 & 15. & 11. & 14. & & & & \\
\hline 28 & 19. & 14. & 14. & Average & 10 & 8.5 & 8.6 \\
\hline
\end{tabular}


Table 4.1.3 Radioparticulate Fallout-1974

(Gummed Paper Data-Station Weekly Average)

\begin{tabular}{|c|c|c|c|}
\hline $\begin{array}{l}\text { Station } \\
\text { Number }\end{array}$ & Location & $\begin{array}{l}\text { Long-Lived Beta Activity } \\
\qquad 10^{-4} \mu \mathrm{Ci} / \mathrm{ft}^{2}\end{array}$ & $\begin{array}{l}\text { Total Particles } \\
\text { Per Sq. Ft.* }\end{array}$ \\
\hline \multicolumn{4}{|c|}{ Laboratory Area } \\
\hline $\mathrm{HP}-1$ & S 3587 & 0.25 & 1.5 \\
\hline$H P=2$ & NE 3025 & 0.25 & 12. \\
\hline$H P=3$ & SW 1000 & 0.19 & 0.19 \\
\hline$H P=4$ & W Settling Basin & 0.23 & 0.0 \\
\hline$H P-5$ & E 2506 & 0.26 & 1.9 \\
\hline$H P-6$ & SW 3027 & 0.19 & 1.4 \\
\hline $\mathrm{HP}-7$ & W 7001 & 0.21 & 0.0 \\
\hline $\mathrm{HP}-8$ & Rock Quarry & 0.21 & 1.9 \\
\hline$H P=9$ & $N$ Bethel Valley Road & 0.20 & 0.19 \\
\hline $\mathrm{HP}-10$ & W 2075 & 0.24 & 1.9 \\
\hline$H P=16$ & E 4500 & 0.21 & 0.38 \\
\hline $\mathrm{HP}=20$ & HFIR & 0.21 & 0.38 \\
\hline Average & & 0.22 & 1.8 \\
\hline \multicolumn{4}{|c|}{ Perimeter Area } \\
\hline $\mathrm{HP}-31$ & Kerr Hollow Gate & 0.22 & \\
\hline $\mathrm{HP}-32$ & Midway Gate & 0.20 & \\
\hline $\mathrm{HP}-33$ & Gallaher Gate & 0.18 & \\
\hline $\mathrm{HP}-34$ & White Oak Dam & 0.19 & \\
\hline $\mathrm{HP}-35$ & Blair Gate & 0.20 & \\
\hline $\mathrm{HP}-36$ & Turnpike Gate & 0.23 & \\
\hline $\mathrm{HP}-37$ & Hickory Creek Bend & 0.19 & \\
\hline $\mathrm{HP}-38$ & E EGCR & 0.20 & \\
\hline $\mathrm{HP}-39$ & Townsite & 0.23 & \\
\hline Average & & 0.21 & \\
\hline \multicolumn{4}{|c|}{ Remote Area } \\
\hline$H P-51$ & Norris Dam & 0.17 & \\
\hline$H P=52$ & Loudoun Dam & 0.16 & \\
\hline $\mathrm{HP}-53$ & Douglas Dam & 0.24 & \\
\hline$H P-54$ & Cherokee Dam & 0.19 & \\
\hline$H P=55$ & Watts Bar Dam & 0.18 & \\
\hline $\mathrm{HP}-56$ & Great Falls Dam & 0.16 & \\
\hline $\mathrm{HP}=57$ & Dale Hollow Dam & 0.18 & \\
\hline$H P-58$ & Knoxville & 0.19 & \\
\hline Average & & 0.18 & \\
\hline
\end{tabular}

* Data determined from autoradiograms. Gummed paper from perimeter and remote areas were not processed by this method during 1974. 
Table 4.1.4 Concentration of Beta Radioactivity in Rainwater-1974

(Weekly Average by Stations)

\begin{tabular}{|c|c|c|}
\hline $\begin{array}{l}\text { Station } \\
\text { Number }\end{array}$ & Location & $\begin{array}{l}\text { Activity in Collected } \\
\text { Rainwater, } 10^{-8} \mu \mathrm{Ci} / \mathrm{ml}\end{array}$ \\
\hline \multicolumn{3}{|c|}{ Laboratory Area } \\
\hline $\mathrm{HP}-7$ & West 7001 & 3.8 \\
\hline \multicolumn{3}{|c|}{ Perimeter Area } \\
\hline$H P=31$ & Kerr Hollow Gate & 3.5 \\
\hline$H P-32$ & Midway Gate & 2.9 \\
\hline$H P=33$ & Gallaher Gate & 4.1 \\
\hline$H P=34$ & White Oak Dam & 4.2 \\
\hline$H P=35$ & Blair Gate & 4.3 \\
\hline$H P-36$ & Turnpike Gate & 3.7 \\
\hline $\mathrm{HP}-37$ & Hickory Creek Bend & 2.7 \\
\hline$H P-38$ & E EGCR & 5.1 \\
\hline$H P-39$ & Townsite & 3.3 \\
\hline Average & & 3.8 \\
\hline \multicolumn{3}{|c|}{ Remote Area } \\
\hline$H P=51$ & Norris Dam & 5.9 \\
\hline$H P-52$ & Loudoun Dam & 9.0 \\
\hline$H P=53$ & Douglas Dam & 7.2 \\
\hline$H P-54$ & Cherokee Dam & 5.9 \\
\hline$H P-55$ & Watts Bar Dam & 5.2 \\
\hline$H P-56$ & Great Falls Dam & 6.0 \\
\hline$H P-57$ & Dale Hollow Dam & 4.8 \\
\hline$H P=58$ & Knoxville & 3.3 \\
\hline Average & & 5.9 \\
\hline
\end{tabular}


Table 4.1.5 Weekly Average Concentration of Beta Radioactivity in Rainwater - 1974

(Units of $10^{-8} \mu \mathrm{Ci} / \mathrm{ml}$ )

\begin{tabular}{|c|c|c|c|c|c|c|c|}
\hline $\begin{array}{l}\text { Week } \\
\text { Number }\end{array}$ & LAM's & PAM's & RAM's & $\begin{array}{l}\text { Week } \\
\text { Number }\end{array}$ & LAM's & PAM's & RAM's \\
\hline 1 & 1.1 & 1.9 & 1.9 & 29 & 3.8 & 4.2 & 8.6 \\
\hline 2 & 0.60 & 1.4 & 1.0 & 30 & 3.1 & 4.8 & 15. \\
\hline 3 & $0.0^{*}$ & $0.0^{*}$ & 2.7 & 31 & 5.6 & 4.8 & 6.7 \\
\hline 4 & 0.90 & 1.8 & 2.0 & 32 & 3.2 & 4.1 & 4.8 \\
\hline 5 & 3.0 & 2.4 & 2.8 & 33 & 2.7 & 3.6 & 5.3 \\
\hline 6 & 4.4 & 5.1 & 7.1 & 34 & 5.5 & 3.1 & 5.9 \\
\hline 7 & 2.6 & 2.3 & 1.7 & 35 & 4.0 & 3.7 & 2.9 \\
\hline 8 & 1.4 & 2.5 & 2.7 & 36 & 3.4 & 2.9 & 4.1 \\
\hline 9 & $0.0 *$ & $0.0^{*}$ & 9.4 & 37 & $0.0^{*}$ & $0.0^{*}$ & 4.6 \\
\hline 10 & 5.3 & 4.2 & 5.6 & 38 & 1.4 & 2.5 & 3.5 \\
\hline 11 & 5.1 & 4.7 & 6.9 & 39 & 1.8 & 1.7 & 2.3 \\
\hline 12 & 3.2 & 3.1 & 5.2 & 40 & $0.0 *$ & $0.0^{*}$ & $0.0^{*}$ \\
\hline 13 & 5.6 & 7.3 & 11. & 41 & $0.0 *$ & $0.0 *$ & $0.0^{*}$ \\
\hline 14 & 4.1 & 4.2 & 5.7 & 42 & 0.90 & 0.26 & 0.95 \\
\hline 15 & 5.9 & 6.1 & 8.9 & 43 & $0.0^{*}$ & $0.0^{*}$ & $0.0^{*}$ \\
\hline 16 & 5.8 & 7.7 & 14 & 44 & $0.0^{*}$ & $0.0^{*}$ & 0.60 \\
\hline 17 & $0.0 *$ & $0.0^{*}$ & 8.8 & 45 & 0.0 & 0.33 & 0.03 \\
\hline 18 & 6.7 & 6.9 & 7.2 & 46 & 0.20 & 1.8 & 1.8 \\
\hline 19 & 6.1 & 7.9 & 10 & 47 & 1.2 & 2.1 & 2.2 \\
\hline 20 & 13 & 7.2 & 7.6 & 48 & 2.1 & 1.6 & 1.7 \\
\hline 21 & 4.6 & 4.1 & 5.6 & 49 & 1.8 & 1.7 & 4.0 \\
\hline 22 & 5.4 & 5.3 & 5.4 & 50 & $0.0^{*}$ & $0.0^{*}$ & 3.2 \\
\hline 23 & 5.1 & 3.4 & 8.6 & 51 & 1.2 & $0.0^{*}$ & 4.7 \\
\hline 24 & 3.5 & 3.5 & 5.8 & 52 & 2.0 & 1.8 & 2.8 \\
\hline 25 & $0.0^{*}$ & $0.0^{*}$ & 21. & & & & \\
\hline 26 & 13. & 8.1 & 19. & & & & \\
\hline 27 & $0.0^{*}$ & 6.1 & 14 & & & & \\
\hline 28 & $0.0^{*}$ & $0.0^{*}$ & 9.6 & Average & 3.7 & 3.8 & 6.1 \\
\hline
\end{tabular}

*No rainfall. 
Table 4.1.6 Weekly Concentration of ${ }^{131}$ I in Air-1974

(Units of $10^{-14} \mu \mathrm{Ci} / \mathrm{cc}$ )

\begin{tabular}{|c|c|c|c|c|c|}
\hline $\begin{array}{l}\text { Week } \\
\text { Number }\end{array}$ & LAM's & PAM's & $\begin{array}{l}\text { Week } \\
\text { Number }\end{array}$ & LAM's & PAM's \\
\hline 1 & 2.5 & 0.6 & 29 & 3.1 & 0.4 \\
\hline 2 & 2.4 & 0.9 & 30 & 2.9 & 1.8 \\
\hline 3 & 3.0. & 0.8 & 31 & 2.8 & 0.8 \\
\hline 4 & $2.2^{\circ}$ & 0.9 & 32 & 3.8 & 1.2 \\
\hline 5 & 2.2 & 0.6 & 33 & 1.0 & 0.4 \\
\hline 6 & 3.1 & 0.8 & 34 & 6.7 & 0.8 \\
\hline 7 & 3.3 & 0.8 & 35 & 2.7 & 0.8 \\
\hline 8 & 2.3 & 0.6 & 36 & 4.7 & 0.8 \\
\hline 9 & 2.6 & 0.8 & 37 & 2.1 & 0.4 \\
\hline 10 & 4.9 & 0.7 & 38 & 3.6 & 1.0 \\
\hline 11 & 6.0 & 0.6 & 39 & 1.9 & 0.5 \\
\hline 12 & 2.9 & 0.5 & 40 & 5.3 & 1.0 \\
\hline 13 & 1.9 & 0.5 & 41 & 5.5 & 1.5 \\
\hline 14 & 1.5 & 0.8 & 42 & 2.9 & 0.7 \\
\hline 15 & 2.4 & 0.7 & 43 & 4.9 & 0.9 \\
\hline 16 & 2.8 & 0.6 & 44 & 1.8 & 0.6 \\
\hline 17 & 2.3 & 0.6 & 45 & 1.7 & 0.8 \\
\hline 18 & 2.6 & 0.9 & 46 & 1.5 & 0.5 \\
\hline 19 & 3.0 & 1.1 & 47 & 2.9 & 1.4 \\
\hline 20 & 2.2 & 0.5 & 48 & 3.6 & 1.1 \\
\hline 21 & 2.6 & 0.9 & 49 & 1.4 & 0.5 \\
\hline 22 & 2.6 & 0.6 & 50 & 3.8 & 1.2 \\
\hline 23 & 1.8 & 0.5 & 51 & 1.7 & 1.5 \\
\hline 24 & 3.2 & 1.0 & 52 & 0.9 & 0.5 \\
\hline 25 & 2.2 & 0.7 & & & \\
\hline 26 & 1.6 & 0.7 & & & \\
\hline 27 & 2.4 & 1.1 & & & \\
\hline 28 & 4.8 & 1.0 & Average & 2.9 & 0.8 \\
\hline
\end{tabular}


Table 4.1.7 Concentration of 131 I in Raw Milk-1974

(Units of $\mathrm{pCi} / \mathrm{l}$ )

\begin{tabular}{c|c|c|c|c}
\hline \multirow{2}{*}{ Quarter } & \multicolumn{2}{|c|}{ Near ORNL } & \multicolumn{2}{c}{ Remote from ORNL } \\
\cline { 2 - 5 } & Average* & Maximum & Average* & Maximum \\
\hline 1 & 0.55 & 2.2 & 1.0 & 3.8 \\
2 & 0.49 & 1.4 & 0.67 & 1.6 \\
3 & $<0.45$ & 0.45 & $<0.45$ & 0.45 \\
4 & $<0.45$ & 0.45 & $<0.45$ & 0.45 \\
\multirow{2}{*}{ Annual } & 0.49 & & 0.65 & \\
\hline
\end{tabular}

* Minimum detectable concentration of ${ }^{131} \mathrm{I}$ in milk is $0.45 \mathrm{pCi} / \mathrm{I}$. The average was obtained by equating all samples less the minimum detectable limit to $0.45 \mathrm{pCi} / \mathrm{l}$.

Table 4.1.8 Concentration of ${ }^{\circ 0} \mathrm{Sr}$ in Raw Milk-1974

(Units of $\mathrm{pCi} / \mathrm{l}$ )

\begin{tabular}{c|c|c|c|c}
\hline \multirow{2}{*}{ Quarter } & \multicolumn{2}{|c|}{ Near ORNL } & \multicolumn{2}{c}{ Remote from ORNL } \\
\cline { 2 - 5 } & Average* $^{*}$ & Maximum & Average* & Maximum \\
\hline 1 & 4.5 & 9.3 & 2.6 & 3.9 \\
2 & 4.4 & 13. & 2.7 & 3.6 \\
3 & 3.9 & 15. & 3.0 & 5.8 \\
4 & 3.4 & 7.2 & 2.6 & 4.0 \\
\multirow{2}{*}{ Annual } & 4.1 & & 2.7 & \\
\hline
\end{tabular}

${ }^{*}$ Minimum detectable limit of ${ }^{90} \mathrm{Sr}$ in milk is $0.5 \mathrm{pCi} / \mathrm{l}$. 
Table 4.1.9 Discharge of ${ }^{131}$ I from ORNL Stacks - 1974*

\begin{tabular}{c|c|c}
\hline \multirow{2}{*}{ Stack Number } & \multicolumn{2}{|c}{ Curies } \\
\cline { 2 - 3 } & Total for Year & Monthly Average \\
\hline 2026 & 0 & 0 \\
3039 & 1.81 & 0.15 \\
3020 & 0 & 0 \\
7512 & 0 & 0 \\
7911 & 0.16 & 0.01 \\
Total & 1.97 & 0.16 \\
\hline
\end{tabular}

* Data furnished by Operations Division. 
Table 4.2.1 Yearly Discharges of Radionuclides to Clinch River (Curies)

\begin{tabular}{llllllll}
\hline Year & ${ }^{137} \mathrm{Cs}$ & ${ }^{106} \mathrm{Ru}$ & ${ }^{90} \mathrm{Sr}$ & ${ }^{95} \mathrm{Zr}$ & ${ }^{95} \mathrm{Nb}$ & $\begin{array}{c}\text { Trans } \mathrm{A} \\
\text { Alpha }\end{array}$ & ${ }^{3} \mathrm{H}$ \\
\hline 1968 & 1.1 & 5 & 2.8 & 0.27 & 0.27 & 0.04 & 9700 \\
1969 & 1.4 & 1.7 & 3.1 & 0.18 & 0.18 & 0.2 & 12200 \\
1970 & 2.0 & 1.2 & 3.9 & 0.02 & 0.02 & 0.4 & 9500 \\
1971 & 0.9 & 0.5 & 3.4 & 0.01 & 0.01 & 0.05 & 8900 \\
1972 & 1.7 & 0.52 & 6.5 & 0.01 & 0.01 & 0.05 & 10600 \\
1973 & 2.3 & 0.69 & 6.7 & 0.05 & 0.05 & 0.08 & 15000 \\
1974 & 1.2 & 0.22 & 6.0 & 0.02 & 0.02 & $0.02 *$ & 8600 \\
\hline
\end{tabular}

* Radionuclides identified from yearly composite sample. Activity composed of ${ }^{239} \mathrm{Pu}, 10 \%{ }^{244} \mathrm{Cm}, 75 \%$; and ${ }^{241} \mathrm{Am}, 15 \%$. 
Table 4.2.2 Radioactivity in Clinch River -1974

\begin{tabular}{|c|c|c|c|c|c|}
\hline \multirow{2}{*}{ Location } & \multicolumn{4}{|c|}{$\begin{array}{l}\text { Concentration of Radionuclides of Primary Concern } \\
\text { Units of } 10^{-9} \mu \mathrm{Ci} / \mathrm{ml}\end{array}$} & \multirow{2}{*}{$\% M P C_{W}$} \\
\hline & $90 \mathrm{Sr}$ & ${ }^{1.37} \mathrm{Cs}$ & ${ }^{106} \mathrm{Ru}$ & ${ }^{3} \mathrm{H}$ & \\
\hline Melton Dam ${ }^{a}$ & 0.09 & 0.03 & 0.10 & 930 & 0.06 \\
\hline $\begin{array}{l}\text { Clinch River at } \\
\text { White Oak Creek }\end{array}$ & 0.89 & 0.16 & 0.04 & 1150 & 0.36 \\
\hline Gallaher $^{a}$ & 0.58 & 0.05 & 0.13 & 1620 & 0.26 \\
\hline Center's Ferry $^{a}$ & 0.45 & 0.08 & 0.31 & 1240 & 0.21 \\
\hline
\end{tabular}

Measured values.

${ }^{b}$ Values given for this location are calculated values based on the concentration of wastes released from White Oak Dam and the dilution afforded by the Clinch River; they do not include radioactive materials $(e . g$. , fallout) that may enter the River upstream from CRM 20.8 . 
Table 4.2.3 Calculated Percent $M P C_{W}$ of ORNL Radioactivity Releases in Clinch River Water Below the Mouth of White Oak Creek-1974

\begin{tabular}{lc}
\hline Month & $\% M P C_{W}$ \\
\hline January & 0.29 \\
February & 0.29 \\
March & 0.58 \\
April & 0.36 \\
May & 0.48 \\
June & 0.35 \\
July & 0.21 \\
August & 0.22 \\
September & 0.23 \\
October & 0.18 \\
November & 0.44 \\
December & 0.68 \\
Average & 0.36 \\
\hline
\end{tabular}


Table 4.2.4 Radionuclide Content of Clinch River Fish-1974

\begin{tabular}{l|c|c|c}
\hline \multirow{2}{*}{ Species } & $p \mathrm{ci} / \mathrm{kg}$ Wet Weight & Estimated \% MPI \\
\cline { 2 - 4 } & $90 \mathrm{Sr}$ & ${ }^{137} \mathrm{Cs}_{5}$ & \\
\hline White Crappie & 43 & 187 & 0.32 \\
Carp & 52 & 27 & 0.36 \\
\hline
\end{tabular}


Table 4.3.1 Radiation Background Data-1974

\begin{tabular}{rlr}
\hline Station No. & \multicolumn{1}{c}{ Location } & $\mu R / h r$ \\
\hline PAM 31 & Kerr Hollow & 8.6 \\
32 & Midway Gate & 10.0 \\
33 & Gallaher Gate & 8.0 \\
34 & White Oak Dam & 12.0 \\
35 & Blair Gate & 6.9 \\
36 & Turnpike Gate & 7.2 \\
37 & Hickory Creek & 7.1 \\
38 & East EGCR & 6.9 \\
& & \\
& Average & 8.3 \\
& & \\
RAM 51 & Norris Dam & 5.1 \\
52 & Loudoun Dam & 6.1 \\
53 & Douglas Dam & 6.9 \\
54 & Cherokee Dam & 7.1 \\
55 & Watts Bar Dam & 5.8 \\
56 & Great Falls Dam & 5.9 \\
57 & Dale Hollow Dam & 6.8 \\
58 & Knoxville & 9.8 \\
& Average & 6.7 \\
& & \\
\hline
\end{tabular}


Table 4.4.1 Soil Samples from Near Perimeter

Air Monitoring Stations-1974

\begin{tabular}{l|c|c|c}
\hline \multirow{2}{*}{$\begin{array}{l}\text { Sampling } \\
\text { Location }\end{array}$} & $\begin{array}{c}\text { Number } \\
\text { Samples }\end{array}$ & \multicolumn{2}{|c}{$\begin{array}{c}\text { Dry Soil } \\
\text { Units of } 10^{-8} \mu \mathrm{Ci} / \mathrm{g}\end{array}$} \\
\cline { 3 - 4 } & & Plutonium(a) & Uranium(a) \\
\hline HP-31 & 1 & 2.9 & 81 \\
HP-32 & 1 & 3.4 & 117 \\
HP-33 & 1 & 2.3 & 50 \\
HP-34 & 1 & 1.9 & 43 \\
HP-35 & 1 & 2.5 & 45 \\
HP-36 & 1 & 0.9 & 43 \\
HP-37 & 1 & 1.8 & 99 \\
HP-38 & 1 & 2.8 & 59 \\
HP-39 & 1 & 2.9 & 113 \\
\hline
\end{tabular}

Nine samples, approximately three inches in diameter and one centimeter thick, were collected in a one square meter area at each location and composited for analysis. 
Table 4.5.1 Environmental Monitoring Samples-1974

\begin{tabular}{llc}
\hline \multicolumn{1}{c}{ Sample Type } & Type of Analyses & $\begin{array}{c}\text { Number } \\
\text { Samples }\end{array}$ \\
\hline $\begin{array}{l}\text { Monitoring network } \\
\text { filters }\end{array}$ & Gross beta, autoradiogram & 1,491 \\
$\begin{array}{l}\text { Gummed paper fallout } \\
\text { trays }\end{array}$ & Gross beta, autoradiogram \\
$\begin{array}{l}\text { Charcoal } \\
\text { Rainwater } \\
\text { White Oak Dam } \\
\text { effluent } \\
\text { Clinch River water }\end{array}$ & $\begin{array}{l}\text { Gross beta } \\
\text { Gaw beta, radiochemical, } \\
\text { gamma spectrometry }\end{array}$ & 1,501 \\
$\begin{array}{l}\text { Potable water } \\
\text { Gross beta, radiochemical, } \\
\text { gamma spectrometry }\end{array}$ & 883 \\
Soil Samples & $\begin{array}{l}\text { Radiochemical } \\
\text { Radiochemical, gamma } \\
\text { spectrometry }\end{array}$ & 738 \\
\hline
\end{tabular}




\subsection{RADIATION AND SAFETY SURVEYS}

\subsection{Laboratory Operations Monitoring}

During 1974, Radiation and Safety Surveys personnel assisted the operating groups in keeping the contamination, air concentration, and personnel exposure levels well below the established maximum permissible limits. Through seminars, safety meetings, and informal discussions with supervision, they assisted in reducing or eliminating a number of problems associated with radiation protection at the Laboratory. The following is a brief description of some of the activities monitored during the year.

\subsubsection{Gamma Irradiation Facility, Building 2001}

A $30 \mathrm{Ci}^{60}$ Co source was installed in Room 120-A, Building 2001, to replace the source removed in 1973. Radiation and Safety Surveys personnel reviewed the design of the new Gamma Irradiation Facility, monitored the installation of the new source, and evaluated the adequacy of the enclosure shielding. Additional shielding was added to the south wall to reduce the radiation field outside the enclosure to $<0.25 \mathrm{mR} / \mathrm{hr}$. Improved safety features were incorporated in the new facility to bring it into compliance with Health Physics Manual Procedure 2.13, "Radiation Protection Guide for High Level Irradiation Facilities".

\subsubsection{Bulk Shielding Reactor, Building 3010}

Monitoring and surveillance were provided for the operations connected with the repair of leaks in the walls of the Bulk Shielding Reactor pool. Some of the fuel elements were transferred to storage in the Oak Ridge Research Reactor pool, other elements and a $2.3 \times 10^{4} \mathrm{Ci}^{60} \mathrm{Co}$ source were stored in the Graphite Reactor canal before the repair work was begun. Other items, such as $D_{2} O$ tanks, the reactor vessel, and the grid assembly, were moved north to the deep pit area of the pool and kept submerged in approximately eight feet of water by installation of a dam. Radiation from this equipment presented a minor problem necessitating working time limits in certain work areas. The work was completed with personnel exposures well below the permissible levels. Surface contamination did not present a significant problem.

\subsubsection{Radiochemical Pilot Plant Operations, Building 3019}

Radiation and Safety Surveys personnel provided assistance in the planning and monitoring of the Chemical Technology Division's operations in support of the Light Water Breeder Reactor Program. During the year, $180 \mathrm{~kg}$ of ${ }^{233} \mathrm{U}\left(<10 \mathrm{ppm}{ }^{232} \mathrm{U}\right)$ were recovered from "scrap" containing $\sim 6.5 \times 10^{3} \mathrm{~kg}$ of $232 \mathrm{Th}$. About $600 \mathrm{~kg}$ of $233 \mathrm{U}$ were processed through the Ion Exchange Purification System, and $\sim 230 \mathrm{~kg}$ of $233 \mathrm{U}$ were processed through the Solvent Extraction Purification System. The Oxide Conversion Facility produced $\sim 415 \mathrm{~kg}$ of ceramic grade ${ }^{23} \mathrm{UO}_{2}$ during the year. 
One hundred thirteen Radiation Work Permits were certified for the more hazardous operations which included: direct maintenance of process equipment in grossly contaminated cells; process sampler systems repairs; process off-gas filter and filter housing replacement; and replacement of cracked windows in two alpha containment boxes.

Containment and protective measures were effective in preventing significant spread of hazardous alpha emitters and internal exposure of personnel. The maximum annual whole body exposure dose equivalent to operating personnel (principally $\beta, \gamma$ from ${ }^{232} U$ daughters) was 1.05 rem.

\subsubsection{Oak Ridge Research Reactor, Building 3042}

Surveillance and assistance were provided during the excavation of the 11,000 gallon Decay Tank for repair of a leak. The leak had been releasing primary coolant water at a rate of 1.5 gallons/minute.

Radiation levels up to $2 \mathrm{R} / \mathrm{hr}$ were encountered along with levels of transferable contamination up to $35 \mathrm{mR} / \mathrm{hr} @ 1 "$. The contamination was effectively confined to the immediate work area. Internal exposures were avoided by the use of plastic suits with a positive air supply. The external exposure was kept well below the permissible limits.

\subsubsection{Oak Ridge Research Reactor, Building 3085}

Assistance and surveillance were provided during the recovery of an irradiated metallic sleeve (containing a quantity of enriched uranium) which was released from the core of the Oak Ridge Research Reactor and lodged in the No. I Primary Coolant Pump at Building 3085.

Despite extremely high radiation levels $(>100 \mathrm{R} / \mathrm{hr}$ ), the recovery was accomplished with a minimum of personnel exposure. The maximum exposure dose received by any individual was $535 \mathrm{mrem}$.

\subsubsection{Environmental Sciences Laboratories 3 and 4, Building 3508}

A complete decontamination and renovation of Laboratories 3 and 4 was required to enable the Environmental Sciences Division to utilize these spaces for tracer level experiments on plant and animal uptake of alpha emitting elements. Eight glove boxes were removed from Laboratory 4, and a large chemical hood from Laboratory 3 . The floor covering was stripped from a section of Laboratory 3 and from all of Laboratory 4. Alpha contaminated concrete was chipped and removed and new concrete poured where decontamination became impossible. Readings up to $5 \times 10^{3} \mathrm{ad} / \mathrm{m}$ were so covered. The maximum direct readings were $<300 \mathrm{ad} / \mathrm{m} / 100 \mathrm{~cm}^{2}$ with smears counting $<30 \mathrm{a} \mathrm{d} / \mathrm{m}$ prior to resurfacing of the floors. 
Readings inside the hood and glove boxes were $>5 \times 10^{5} \mathrm{ad} / \mathrm{m} / 100 \mathrm{~cm}^{2}$ and may have been from any or all of the following isotopes: ${ }^{238} \mathrm{Pu},{ }^{239} \mathrm{Pu},{ }^{233} \mathrm{U},{ }^{235} \mathrm{U}$, ${ }^{241} \mathrm{Am},{ }^{244} \mathrm{Cm}$, and ${ }^{252} \mathrm{Cf}$. These items were enclosed in plywood boxes lined with heavy plastic and stored in metal storage cases. All waste (mops, wipes, rags, shoe covers, gloves, contaminated concrete, etc.) not placed within the plywood boxes was transferred to Solid Waste Storage in stainless steel drums.

Approximately six months were required for completion of this job with almost continuous surveillance. Spread of contamination was confined to the hallway outside the labs and was less than $100 \mathrm{~d} / \mathrm{m} / 100 \mathrm{~cm}^{2}$. External exposure doses were within permissible limits and bio-assay results indicated no internal deposition of radioisotopes.

\subsubsection{High-Level Radiochemical Laboratory, Building 4501}

Health Physics surveillance was provided for the removal and replacement of about 400 feet of a leaking radioactive waste line in the hot tunnel of Building 4501 . Radiation levels up to $10 \mathrm{R} / \mathrm{hr}$ and contamination levels exceeding $10^{5} \alpha \mathrm{d} / \mathrm{m}$ were measured at surfaces in the work area. Contamination control precautions succeeded in keeping personnel exposures within permissible limits and prevented any significant releases.

An extensive renovation of the facilities in Laboratory 127 was completed. This project necessitated the separation of a plutonium-contaminated glove box line, the disposal of two of the glove boxes, the removal and disposal of a contaminated hood, and the installation of new filter housings and high efficiency filters on the remaining boxes. Cooperation between all individuals involved in the planning and execution of the project was excellent. No significant contamination of personnel or facilities was detected at any time.

\subsubsection{Transuranium Research Laboratory (TRL), Building 5505}

The TRL Radiation and Safety Surveys staff continued to provide protective technical support to experimental programs involving the investigation of chemical properties of transuranium elements and nuclear properties of their isotopes. This activity included working directly with individual researchers in designing appropriate containment enclosures and procedures, assembling and disassembling apparatus, conducting various experiments, decontamination, and the disposal of radioactive wastes.

A number of training activities were conducted during the year, including lectures and demonstrations for the ORAU 10-Week Health Physics class, college professors attending the Health Physics Summer Institute, visiting students from various universities, members of the Electrical Department of the Plant and Equipment Division, new engineers in the Engineering Division, and 75 students at Robertsville Junior High School in Oak Ridge. 


\subsubsection{Oak Ridge Electron Linear Accelerator (ORELA), Building 6010}

Radiation and Safety Surveys personnel assisted in ORELA beam profile studies. Nickel foils were irradiated by the electron beam under several beam optics conditions. Detailed beam distribution patterns were determined by scanning the foils with a small, finely collimated Geiger tube. The data were used to assist in predicting heat flow distribution in the ORELA target and to determine the maximum beam power that the target could safely absorb.

\subsubsection{Health Physics Research Reactor, Building 7710}

The reactor core was disassembled for inspection and reassembled prior to the annual dosimeter intercomparison studies at the HPRR. Both of these operations required continuous Health Physics surveillance. Personnel exposures were kept to a minimum and there was no release of contamination.

\subsubsection{Transuranium Processing Plant, Building 7920}

Modification of processing equipment in the cell pits and cubicles was performed again during the summer of 1974. Remote maintenance techniques and close surveillance from Health Physics were required due to the very high concentrations of transuranium alpha emitters and high neutron and gamma dose rates encountered. Pre-filters used to remove organic vapors from the vessel off-gas line were changed in the pipe tunnel. Extraordinary measures to contain airborne contamination are required in this operation because of the small particle sizes and the high level of alpha contamination contained in the filters.

\subsubsection{Thorium-Uranium Recycle Facility, Building 7930}

Assistance was given personnel setting up an experiment in Cell B. Various types of fast neutron detectors were tested using $a^{252} \mathrm{Cf}$ source and $a^{60} \mathrm{Co}$ source to determine the gamma sensitivity of the neutron detectors in a mixed field of radiation.

\subsubsection{Oak Ridge Tokamak (ORMAK), Building 9201-2}

ORMAK continued operation during 1974 with personnel exposures well below permissible levels. During the months of June and July, experiments included runs with deuterium gas plasma and auxiliary heating of the plasma by the injection of deuterium neutrals into both a hydrogen gas plasma and a deuterium plasma. This operation was monitored for $X$-radiation and neutrons using TLD's and portable instruments. No increase in X-radiation level was noted, and there was only an insignificant indication of neutrons.

Another significant step in fusion reactor research was taken in December with the installation of two new injectors. These two injectors combined with the two previous 
$100 \mathrm{~kW}$ systems make a total of $500 \mathrm{~kW}$ of supplemental plasma heating power available. Preliminary indications are that there is little or no increase in $X$-radiation levels.

\subsubsection{Survey of X-Ray Equipment}

In a continuing effort to meet the increased requirements of federal safety standards, the program for installing light failure alarm systems on analytical $X$-ray devices was completed (these devices sound a buzzer if the $X$-ray indicating light fails).

A new interlock and safety system was designed and installed at a large radiographic facility. The design ensures that a failure of any one item in the interlock and safety system will not violate the integrity of the system.

A study was made to determine how effective TLD's would be as hand exposure meters for monitoring people working with analytical X-ray units. Results indicated that an exposure of greater than $200 \mathrm{R}$ would not be clearly indicated if the edge of the ring were more than $1 / 4$-inch from the point of exposure.

The annual survey of $X$-ray machines was completed. The review focused mainly on clear identification of work areas and $X$-ray machines, $X$-ray leakage measurements, interlock systems and safety devices, identity of persons responsible for or operating $X$-ray machines, changes in equipment or experiments, and electrical safety and procedures. An Instrumentation and Controls engineer accompanied the health physicist on the review to assist in reviewing the safety interlock systems and electrical safety.

\subsubsection{Survey of Microwave-Generating Equipment}

Microwave ovens constitute the major source of potential microwave hazard at ORNL. The number of ovens increased significantly during the last year. There are now 11 microwave ovens. The ovens were surveyed quarterly, and microwave leakage in every case was well below established limits. Excessive foreign matter on door seals caused minor leakage in two instances. Signs indicating hazards and instructions for safe use have been posted by all known canteen and lunchroom microwave ovens.

A safety procedure for the operation and registration of microwave-generating equipment was added to the Health Physics Manual.

\subsubsection{Salient Items from Shift-Area Surveys Complex}

Radiation and Safety Surveys assistance in the form of radiation/contamination level monitoring surveillance and personnel exposure control through Radiation Work Permit issuance and certification was provided throughout the facility improvement program at the Shale Fracture site. The work was done to overcome a number of operational difficulties experienced and included decontamination and removal of 
major equipment items such as the mixing tub and ventilation system from the mixing cell. A new, stainless steel mixing tank with improved configuration, new stainless steel piping, a better cell ventilation system, improved instrumentation, and lead shielding over pipelines in the well cell were then installed. The work extended over a two-month period and resulted in a much improved facility.

A closely related project, which was assisted to successful completion by the monitoring efforts of Radiation and Safety Surveys personnel, was the injection of $\sim 20$ curies of ${ }^{198}$ Au into the fractures in the new well to be used for liquid waste disposal. The distribution of the radioactive gold was logged from the observation wells in the area to show that the fractures stemming from the well were, in fact, in horizontal planes. This work was a cooperative effort by the Laboratory and the Halliburton Well-Drilling Company, and was completed with only minimal exposures and no contamination releases.

Another facility improvement effort which required Radiation and Safety Surveys assistance was the connection of W-5 Tank in the South Tank Farm area to the Plant off-gas system by Rust Engineering Company personnel. The off-gas service to W-5 has made an important reduction in the waste gases previously only filtered and vented to atmosphere in both the North and South Tank Farm areas. The work was completed satisfactorily under carefully controlled conditions for exposures.

\subsection{Radiation Surveys Made Off-Area}

Beginning on October 14, 1974 (and continuing at the end of the year), Radiation and Safety Surveys surveillance was provided on a continuous basis for the clean-up effort at the American Nuclear Corporation site. The Corporation had conducted a licensed operation (handling ${ }^{60} \mathrm{Co}$ and ${ }^{137} \mathrm{C}_{5}$ ) which was shut down due to unsatisfactory performance. Kilocurie quantities of both isotopes were left in the facility at the time of the shutdown. Conditions at the site were judged unsatisfactory and ORNL was designated to perform recovery and site clean-up.

The scope of this operation cannot be conveyed in this space. It did progress satisfactorily, with monitoring required before, during, and after each step in the effort. Personnel exposures were kept within permissible limits and some 29 escorted truckloads (with more to come) of radioactive materials and contaminated material were removed to ORNL for final disposal with no significant release to the environment.

During April, a representative from the Radiation and Safety Surveys Section provided on-the-job surveillance for the "RIST Program" planned by the National Oceanographic and Atmospheric Administration (NOAA). The experiment was conducted near New York Harbor as part of a continuing study to plot the movement of Harbor sediment. Sand, tagged with ${ }^{106} \mathrm{Ru}$, was deposited on the ocean floor, and its subsequent movements traced with a submersible scintillation counter. Careful handling of the material and close cooperation of all participating personnel resulted in excellent control of personnel exposures and radioactive contamination. 


\subsection{Unusual Occurrences}

Radiation incidents are classified according to a severity index system developed over the past several years (see ORNL-3665, Applied Health Physics Annual Report for 1963, pp. 14-15). The method serves to index unusual occurrences according to degree of severity and permits a system of analysis regarding Applied Health Physics and Safety practices among Laboratory operations.

During 1974, there were 10 unusual occurrences recorded which is the same as the number recorded for 1973 (Table 5.3.1, page 46). The number for 1974, 10, is the same as the five-year average for the years 1970-1974. The frequency rate of unusual occurrences among Laboratory divisions involved (Table 5.3.2, page 47) is known to vary in relationship to the quantity of radioactive materials handled, the number of radiation workers involved, and the radiation potential associated with a particular operation or facility.

Five of the incidents reported during 1974 were of minor consequence, involving personnel exposures below MPE limits, and required little or no cleanup effort. Three of the incidents involved area contamination that was handled by the regular work staff without appreciable production or program loss. Two of the incidents were contamination of work areas that required interdepartmental assistance with minor departmental program loss.

\subsection{Laundry Monitoring}

There were approximately 392,100 articles of wearing apparel monitored at the Laundry during 1974. Approximately 13 percent were found contaminated. Of 227,737 khaki garments monitored, only 100 were found contaminated.

A total of 6,680 full-face respirators and 4,909 cannisters were monitored (at the Laundry) during the year. Among these items, 874 pieces required additional action after the first cleaning cycle. 
Table 5.3.1 Unusual Occurrences Summarized for the 5-Year Period Ending with 1974

\section{$1970 \quad 1971 \quad 1972 \quad 1973 \quad 1974$}

Number of Unusual Occurrences Recorded . . . . $99 \begin{array}{clllll}10 & 9 & 11 & 10 & 10\end{array}$

A. Number of incidents of minor consequence involving personnel exposure below MPE limits and requiring little or no cleanup effort..................... 2 1 2 7 5

B. Number of incidents involving personnel exposure above MPE limits and/or resulting in special cleanup effort as the result of contamination ............. 7 9 9 9 35

1. Personnel Exposures. . . . . . . . . . . . 1 1 3 444

a. Nonreportable overexposures with minor work restrictions imposed. . . . . $110 \begin{array}{llllll} & 3 & 4 & 4 & 4\end{array}$

b. Reportable overexposures with

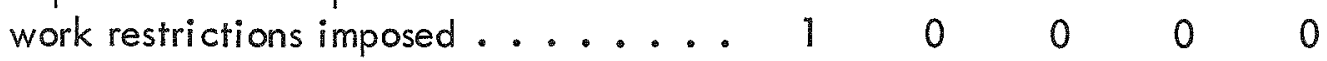

2. Contamination of Work Area ....... 69996

a. Contamination that could be handled by the regular work staff with no appreciable departmental program

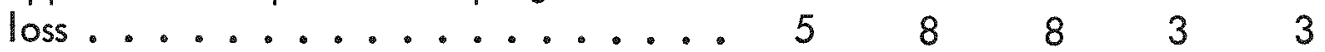

b. Required interdepartmental assistance with minor departmental program loss................. 1 1 1 1 1 o 2

c. Resulted in halting or temporarily deterring parts of the Laboratory program................... 0 o 0 o 00 
Table 5.3.2 Unusual Occurrence Frequency Rate within the Divisions for the 5-Year Period Ending with 1974

\begin{tabular}{|c|c|c|c|c|c|c|c|}
\hline Division & $\frac{\text { No. }}{1970}$ & $\frac{\text { of Unv }}{1971}$ & $\frac{1 \text { sual }}{1972}$ & $\frac{\text { Decurre }}{1973}$ & $\frac{\text { ences }}{1974}$ & $\begin{array}{l}\text { 5-Year } \\
\text { Total }\end{array}$ & $\begin{array}{c}\text { Percent } \\
\text { Lab. Total } \\
(5-\text { Year Period })\end{array}$ \\
\hline Analytical Chemistry & & 1 & 1 & & & 2 & 4.0 \\
\hline Biology & & & & & 1 & 1 & 2.0 \\
\hline Chemical Technology & 2 & 1 & 1 & 4 & 3 & 11 & 24.0 \\
\hline Chemistry & & 1 & 1 & & 1 & 3 & 6.0 \\
\hline Environmental Sciences & & & & 1 & & 1 & 2.0 \\
\hline Health Physics & & & & 1 & & 1 & 2.0 \\
\hline Inspection Engineering & 1 & & & & & 1 & 2.0 \\
\hline Isotopes & 3 & 4 & 5 & & 2 & 14 & 28.0 \\
\hline Metals and Ceramics & 1 & 1 & & & & 2 & 4.0 \\
\hline Operations & 2 & 2 & 2 & 3 & 1 & 10 & 20.0 \\
\hline Physics & & & 1 & & & 1 & 2.0 \\
\hline Reactor Chemistry & & & & 1 & & 1 & 2.0 \\
\hline Solid State & & & & & 1 & 1 & 2.0 \\
\hline TOTALS & $\overline{9}$ & $\overline{10}$ & $\overline{11}$ & $\overline{10}$ & $\overline{10}$ & $\overline{50}$ & $\overline{100.0}$ \\
\hline
\end{tabular}




\subsection{INDUSTRIAL SAFETY AND SPECIAL PROJECTS}

The safety record for 1974 was very good compared to nationwide industrial experience and with other installations performing the same type of work. Although there were more Disabling Injuries recorded in 1974 than in 1973, none of the Disabling Injuries resulted in any permanent disability to an employee; and the days lost were the lowest of the last five years. The number and frequency rate of Serious Injuries was the lowest of the last five years (1970-1974).

\subsection{Accident Analyses}

The Disabling Injury frequency rate for 1974 was 0.81 compared with a frequency rate of 0.33 for 1973 , the 1973 rate being the third best in the history of the Laboratory. The Serious Injury frequency rate for 1974 was 4.9 compared with a frequency rate of 5.8 for 1973 . The 4.9 frequency rate for 1974 equals the best record in the hist ory of the Laboratory. The injury statistics for ORNL for the period 1960-1974 are shown in Table 6.1.1, page 51. The Disabling Injury history of ORNL for the past five years is shown in Table 6.1.2, page 52; and the Disabling Injury frequency rates since the inception of Carbide's contract as compared with the frequency rates for NSC, ERDA, and UCC are shown in Table 6.1.3, page 53.

Figure 6.1.1, page 62, shows the ORNL injury statistics averaged by ten-year intervals. It is noted that the frequency rate for the last ten-year period (1965-1974) was less than half the frequency rate for the ten-year period from 1945 through 1954.

Twelve divisions at ORNL did not have a Serious or Disabling Injury in 1974. Injury statistics by division are shown in Table 6.1.4, page 54 .

Disabling Injury accident-free periods for ORNL are shown in Table 6.1.5, page 55. The longest accident-free period, as noted, was from July 4, 1968, through August 20, 1969. Within that period the Laboratory accumulated just over 8.5 million man-hours.

Tables 6.1.6, 6.1.7, and 6.1.8, pages 56, 57, and 58, present ORNL injury data according to accident type, part of body injured, and nature of injury. Laceration of fingers continues to be the major cause of injuries.

A tabulation of injuries for the four UCC-ND facilities is shown in Table 6.1.9, page 59. ORNL and Paducah had the highest frequency rates for Disabling Injuries, 0.81 , but ORNL had the lowest frequency rate for Serious Injuries, 4.85 .

Statistics on motor vehicle accidents, fires, and off-the-job Disabling Injuries are shown in Tables 6.1.10,6.1.11, and 6.1.12, pages 60 and 61 . The increase 
shown for off-the-job Disabling Injuries in 1974 is attributed to an improved procedure for obtaining information on off-the-job injuries. Off-the-job injuries are currently noted on the time card record.

\subsection{Summary of Disabling Injuries}

Following are summaries of the five Disabling Injuries experienced at ORNL in 1974:

Date of In jury $-1 / 16 / 74$

A rigger was performing a routine operation of rearranging stainless steel plates $\left(5^{1} \times 5^{3}\right.$ with varying thicknesses) at the Tower Shielding Facility. During the rearranging process, one of the plates fell, grazing the left leg and landing on the left foot of the employee. The injury resulting from the incident was a fracture, second proximal metatarsal, left foot, and contusion and abrasions, left ankle and foot. Later it was determined that there was ten percent Permanent Partial Disability to the left foot. Time loss: 240 days.

Date of In jury $-5 / 7 / 74$

A janitor was wet mopping a wax-water solution from a tiled concrete floor. As he was using the mop, he slipped and fell, striking his right elbow on the floor. The injury resulting from the incident was severe contusion and sprain of the elbow. The employee was released by the doctor to return to work with temporary restriction on use of the right elbow. The employee's supervision had no job available which could be performed under the work restriction imposed. Time loss: 12 days.

Date of Injury $-6 / 16 / 74$

A mathematician was standing on a ramp just outside a doorway and started to squat on his heels to rest. As he went down, his coccyx area of the buttock struck against a doorstop. At the time of the incident, the pain was sufficient to be noticeable; however, the employee did not attach any significance to the injury. After several days, the bruised area became swollen and painful. Surgery was required to drain a peri-rectal abscess that had formed. Time loss: 8 days.

Date of Injury $-8 / 12 / 74$

A carpenter was finishing a small piece of wood on a jointer. While making the first cut, his left hand slipped off the piece, striking the cutter. The resulting injury was transverse amputation, distal phalanx, left thumb, and abrasions and lacerations to the left long finger. Time loss: 48 days. 
Date of Injury $-12 / 6 / 74$

A laborer was riding on the front seat of a carryall. While the driver was maneu= vering the vehicle to turn, the employee, thinking the vehilce had stopped, started to step out. The vehicle was still moving slightly, and the door struck a fire hydrant guard post. His left leg was squeezed between the door and door sill. The injury resulting from the incident was crushing of the middle portion of the leg. Time loss: 7 days.

\subsection{Safety Awards}

ORNL employees failed to achieve a 120-day period without a Disabling Injury during 1974. From January 17, 1974, through May 6, 1974, the Laboratory employees worked 1.8 million man-hours without a Disabling Injury. From August 13, 1974, through December 5, 1974, the Laboratory worked just over two million man-hours without a Disabling Injury, missing the 120-day accident-free period by only four days. 
Table 6.1.1 ORNL Injury Statistics (1960-1974)

\begin{tabular}{|c|c|c|c|c|c|}
\hline \multirow{2}{*}{ Year } & \multicolumn{3}{|c|}{ Disabling Injuries } & \multicolumn{2}{|c|}{ Serious Injuries } \\
\hline & Number & Frequency & Severity & Number & Frequency \\
\hline 1960 & 6 & 0.94 & 77 & 99 & 15.5 \\
\hline 1961 & 10 & 1.55 & 576 & 80 & 12.4 \\
\hline 1962 & 10 & 1.45 & 377 & 70 & 10.2 \\
\hline 1963 & 11 & 1.55 & 172 & 58 & 8.2 \\
\hline 1964 & 8 & 1.07 & 148 & 83 & 11.1 \\
\hline 1965 & 18 & 2.34 & 366 & 97 & 12.6 \\
\hline 1966 & 5 & 0.64 & 155 & 93 & 11.9 \\
\hline 1967 & 4 & 0.50 & 266 & 89 & 11.1 \\
\hline 1968 & 1 & 0.13 & 8 & 73 & 9.4 \\
\hline 1969 & 2 & 0.27 & 9 & 37 & 4.9 \\
\hline 1970 & 5 & 0.76 & 88 & 49 & 7.5 \\
\hline 1971 & 4 & 0.61 & 298 & 38 & 5.8 \\
\hline 1972 & 7 & 1.08 & 52 & 49 & 7.6 \\
\hline 1973 & 2 & 0.33 & 24 & 35 & 5.8 \\
\hline 1974 & 5 & 0.81 & 51 & 30 & 4.9 \\
\hline
\end{tabular}


Table 6.1.2 Disabling Injury History-ORNL (1970-1974)

\begin{tabular}{lrrrrr}
\hline & 1970 & 1971 & 1972 & 1973 & 1974 \\
\hline Number of Injuries & 5 & 4 & 7 & 2 & 5 \\
Labor Hours (Millions) & 6.6 & 6.5 & 6.5 & 6.0 & 6.2 \\
Frequency Rate & 0.76 & 0.61 & 1.08 & 0.33 & 0.81 \\
Days Lost or Charged & 577 & 1944 & 337 & 692 & 315 \\
Severity Rate & 88 & 298 & 52 & 115 & 51 \\
\hline
\end{tabular}


Table 6.1.3 ORNL Disabling Injury Frequency Rates Since Inception of Carbide Contract Compared with Frequency Rates for NSC, ERDA and UCC

\begin{tabular}{|c|c|c|c|c|}
\hline Year & ORNL & NSC & ERDA & UCC \\
\hline 1948 & 2.42 & 11.49 & 5.25 & 5.52 \\
\hline 1949 & 1.54 & 10.14 & 5.35 & 4.91 \\
\hline 1950 & 1.56 & 9.30 & 4.70 & 4.57 \\
\hline 1951 & 2.09 & 9.06 & 3.75 & 4.61 \\
\hline 1952 & 1.39 & 8.40 & 2.70 & 4.37 \\
\hline 1953 & 1.43 & 7.44 & 3.20 & 3.61 \\
\hline 1954 & 0.79 & 7.22 & 2.75 & 3.02 \\
\hline 1955 & 0.59 & 6.96 & 2.10 & 2.60 \\
\hline 1956 & 0.55 & 6.38 & 2.70 & 2.27 \\
\hline 1957 & 1.05 & 6.27 & 1.95 & 2.41 \\
\hline 1958 & 1.00 & 6.17 & 2.20 & 2.21 \\
\hline 1959 & 1.44 & 6.47 & 2.15 & 2.16 \\
\hline 1960 & 0.94 & 6.04 & 1.80 & 1.92 \\
\hline 1961 & 1.55 & 5.99 & 2.05 & 2.03 \\
\hline 1962 & 1.45 & 6.19 & 2.00 & 2.28 \\
\hline 1963 & 1.55 & 6.12 & 1.60 & 2.10 \\
\hline 1964 & 1.07 & 6.45 & 2.05 & 2.20 \\
\hline 1965 & 2.34 & 6.53 & 1.80 & 2.40 \\
\hline 1966 & 0.64 & 6.91 & 1.75 & 2.57 \\
\hline 1967 & 0.50 & 7.22 & 1.55 & 2.06 \\
\hline 1968 & 0.13 & 7.35 & 1.27 & 2.24 \\
\hline 1969 & 0.27 & 8.08 & 1.52 & 2.49 \\
\hline 1970 & 0.76 & 8.87 & 1.28 & 2.27 \\
\hline 1971 & 0.61 & 9.37 & 1.44 & 2.05 \\
\hline 1972 & 1.08 & 10.17 & 1.40 & 1.73 \\
\hline 1973 & 0.33 & 10.55 & 1.45 & 1.50 \\
\hline 1974 & 0.81 & - & - & 0.99 \\
\hline
\end{tabular}


Table 6.1.4 Injury Statistics by Division -1974

\begin{tabular}{|c|c|c|c|c|c|c|c|}
\hline \multirow{2}{*}{ Division } & \multirow{2}{*}{$\begin{array}{l}\text { Medical } \\
\text { Treatment } \\
\text { Cases }\end{array}$} & \multicolumn{2}{|c|}{$\begin{array}{l}\text { Serious } \\
\text { Injuries }\end{array}$} & \multicolumn{3}{|c|}{ Disabling Injuries } & \multirow{2}{*}{$\begin{array}{c}\text { Exposure } \\
\text { Hours } \\
\text { (In Millions) }\end{array}$} \\
\hline & & No. & Freq. & Number & Freq. & Sev. & \\
\hline Analytical Chemistry & 7 & 1 & 5.00 & & & & .200 \\
\hline Chemical Technology & 16 & 2 & 4.35 & & & & .459 \\
\hline Chemistry & 4 & 0 & 0 & & & & .147 \\
\hline Director's & 3 & 0 & 0 & & & & .093 \\
\hline Physics & 7 & 0 & 0 & & & & .178 \\
\hline Instr. and Controls & 30 & 1 & 2.21 & & & & .452 \\
\hline Health Physics & 8 & 0 & 0 & & & & .281 \\
\hline Metals and Ceramics & 21 & 0 & 0 & & & & .406 \\
\hline Neutron Physics & 4 & 1 & 7.94 & & & & .126 \\
\hline Computer Sciences & 13 & 1 & 2.92 & 1 & 2.92 & 23 & .342 \\
\hline Reactor & 1 & & & & & & .004 \\
\hline Solid State & 2 & 0 & 0 & & & & .125 \\
\hline Engineering & 8 & 0 & 0 & & & & .334 \\
\hline Health & 2 & 0 & 0 & & & & .048 \\
\hline Inspection Engineering & 4 & 0 & 0 & & & & .058 \\
\hline Laboratory Protection & 10 & 0 & 0 & & & & .145 \\
\hline Operations & 36 & 2 & 6.15 & 1 & 3.07 & 37 & .325 \\
\hline Employee Relations & 15 & 1 & 8.52 & & & & .117 \\
\hline Plant and Equipment & 366 & 14 & 10.15 & 3 & 2.18 & 214 & 1.379 \\
\hline Information & 13 & 1 & 3.83 & & & & .261 \\
\hline Isotopes & 11 & 1 & 7.60 & & & & .131 \\
\hline Environmental Sciences & 10 & 1 & 4.79 & & & & .209 \\
\hline MAN & 2 & 0 & 0 & & & & .043 \\
\hline Energy & 0 & 0 & 0 & & & & .095 \\
\hline Finance and Materials & 22 & 4 & 17.8 & & & & .225 \\
\hline PLANT TOTAL & 615 & 30 & 4.85 & 5 & 0.81 & 51 & 6.183 \\
\hline
\end{tabular}


Table 6.1.5 Disabling Injury Accident-Free Periods-ORNL (1970-1974)

October 22, 1969 - April 12, 1970

$3,322,364$

April 14, 1970 - September 7, 1970

$2,488,194$

September 9, 1970 - September 22, 1970

281,630

September 24, 1970 - October 27, 1970

597,271

October 30, 1970 - February 18, 1971

$2,051,309$

February 20, 1971 - May 24, 1971

$1,802,520$

May 26, 1971 - September 8, 1971

$1,831,697$

September 10, 1971 - September 25, 1971

238,413

September 27, 1971 - January 23, 1972

$2,021,680$

January 25, 1972 - April 10, 1972

$1,396,282$

April 12, 1972 - June 20, 1972

$1,262,911$

June 22, 1972 - June 29, 1972

151,434

July 1, 1972 - October 15, 1972

$1,874,592$

October 17, 1972 - November 19, 1972

630,669

November 21, 1972 - December 10, 1972

296,276

December 12, 1972 - April 25, 1973

$2,327,051$

April 27, 1973 - July 29, 1973

$1,428,975$

July 31, 1973 - January 15, 1974

$2,760,549$

January 17, 1974 - May 6, 1974

$1,869,338$

May 8, 1974 - June 15, 1974

661,399

June 17, 1974 - August 11, 1974

926,437

August 13, 1974 - December 5, 1974

$2,010,547$

Best Accident-Free Period

July 4, 1968 - August 20, 1969

$8,529,750$ 
Table 6.1.6 Number and Percent of Accidents by Type

\begin{tabular}{|c|c|c|}
\hline Type of Accident & Number & Percent \\
\hline Struck Against & 192 & 31.3 \\
\hline Struck By & 145 & 23.7 \\
\hline Slip, Twist & 93 & 15.2 \\
\hline Caught In, On, Between & 59 & 9.6 \\
\hline Contact with Temp. Extremes & 28 & 4.6 \\
\hline Fall, Same Level & 19 & 3.1 \\
\hline Inhalation, Absp., Ingestion & 7 & 1.1 \\
\hline Fall, Different Level & 7 & 1.1 \\
\hline Other & 63 & 10.3 \\
\hline TOTAL & 613 & 100.0 \\
\hline
\end{tabular}


Table 6.1.7 Number and Percent of Accidents Relative to Part of Body Injured

\begin{tabular}{lcc}
\multicolumn{1}{c}{ Body Area } & Number & Percent \\
\hline Finger & 167 & 27.2 \\
Hands & 77 & 12.6 \\
Arms & 72 & 11.8 \\
Back & 63 & 10.3 \\
Head & 63 & 10.3 \\
Leg & 43 & 7.0 \\
Eye & 40 & 6.5 \\
Feet & 34 & 5.5 \\
Lower Trunk & 37 & 4.4 \\
Shoulders, Chest & 22 & 3.6 \\
Orher & 513 & 0.8 \\
TOTAL & 5 & 100.0 \\
\hline
\end{tabular}


Table 6.1.8 Number and Percent of Accidents by Nature of Injury

\begin{tabular}{lcc}
\hline Nature of Injury & Number & Percent \\
\hline Laceration, Puncture & 195 & 31.8 \\
Contusion, Abrasion & 132 & 21.5 \\
Strain & 95 & 15.5 \\
Burn, Temperature & 40 & 6.5 \\
Sprain & 16 & 2.6 \\
Conjunctivitis & 12 & 2.0 \\
Bum, Chemical & 10 & 1.6 \\
Other & 119 & 18.5 \\
TOTAL & 613 & 100.0 \\
\hline
\end{tabular}


Table 6.1.9 Tabulation of Injuries by UCC-ND Facility-1974

\begin{tabular}{l|c|c|c|c|c|c|c}
\hline \multirow{2}{*}{ Plant } & $\begin{array}{c}\text { Labor } \\
\text { Hours } \\
\text { (Millions) }\end{array}$ & $\begin{array}{c}\text { Number of } \\
\text { Injuries }\end{array}$ & $\begin{array}{c}\text { Frequency } \\
\text { Rate }\end{array}$ & $\begin{array}{c}\text { Days Lost } \\
\text { or Charged }\end{array}$ & $\begin{array}{c}\text { Severity } \\
\text { Rate }\end{array}$ & $\begin{array}{c}\text { Number of } \\
\text { Injuries* }\end{array}$ & $\begin{array}{c}\text { Frequency } \\
\text { Rate }\end{array}$ \\
\cline { 3 - 8 } ORNL & 6.2 & 5 & 0.81 & 315 & 51 & 30 & 4.85 \\
ORGDP & 6.6 & 3 & 0.45 & 227 & 34 & 52 & 7.85 \\
Y-12 & 11.5 & 1 & 0.09 & 119 & 10 & 77 & 6.67 \\
Paducah & 2.4 & 2 & 0.81 & 35 & 14 & 25 & 10.2 \\
\hline
\end{tabular}

*Includes the number of Disabling Injuries. 
Table 6.1.10 Motor Vehicle Accidents (1970-1974)

\begin{tabular}{llll}
\hline Year & Number & Frequency & Damage \\
\hline 1970 & 17 & 9.04 & $\$ 2886$ \\
1971 & 15 & 7.66 & $\$ 3595$ \\
1972 & 12 & 5.93 & $\$ 4641$ \\
1973 & 10 & 5.22 & $\$ 915$ \\
1974 & 15 & 8.14 & $\$ 1968$ \\
\hline
\end{tabular}

Table 6.1.11 Number of Fires (1970-1974)

\begin{tabular}{|c|c|c|}
\hline Year & Number & Damage \\
\hline 1970 & 3 & $\$ 0$ \\
\hline 1971 & 21 & $\$ 0$ \\
\hline 1972 & 23 & $\$ 0$ \\
\hline 1973 & 20 & $\$ 300$ \\
\hline 1974 & 8 & $\$ 0$ \\
\hline
\end{tabular}


Table 6.1.12 Number and Type of Off-The-Job Disabling Injuries (1972-1974)

\begin{tabular}{lrrr}
\hline & 1972 & 1973 & 1974 \\
\hline Transportation & 3 & 3 & 8 \\
Home & 11 & 3 & 17 \\
Public & 3 & 5 & 10 \\
Total & 17 & 13 & 35 \\
Days Lost & 990 & 612 & 1197 \\
Frequency & 1.25 & 1.01 & 2.54 \\
Fatalities & 0 & 1 & 2 \\
\hline
\end{tabular}




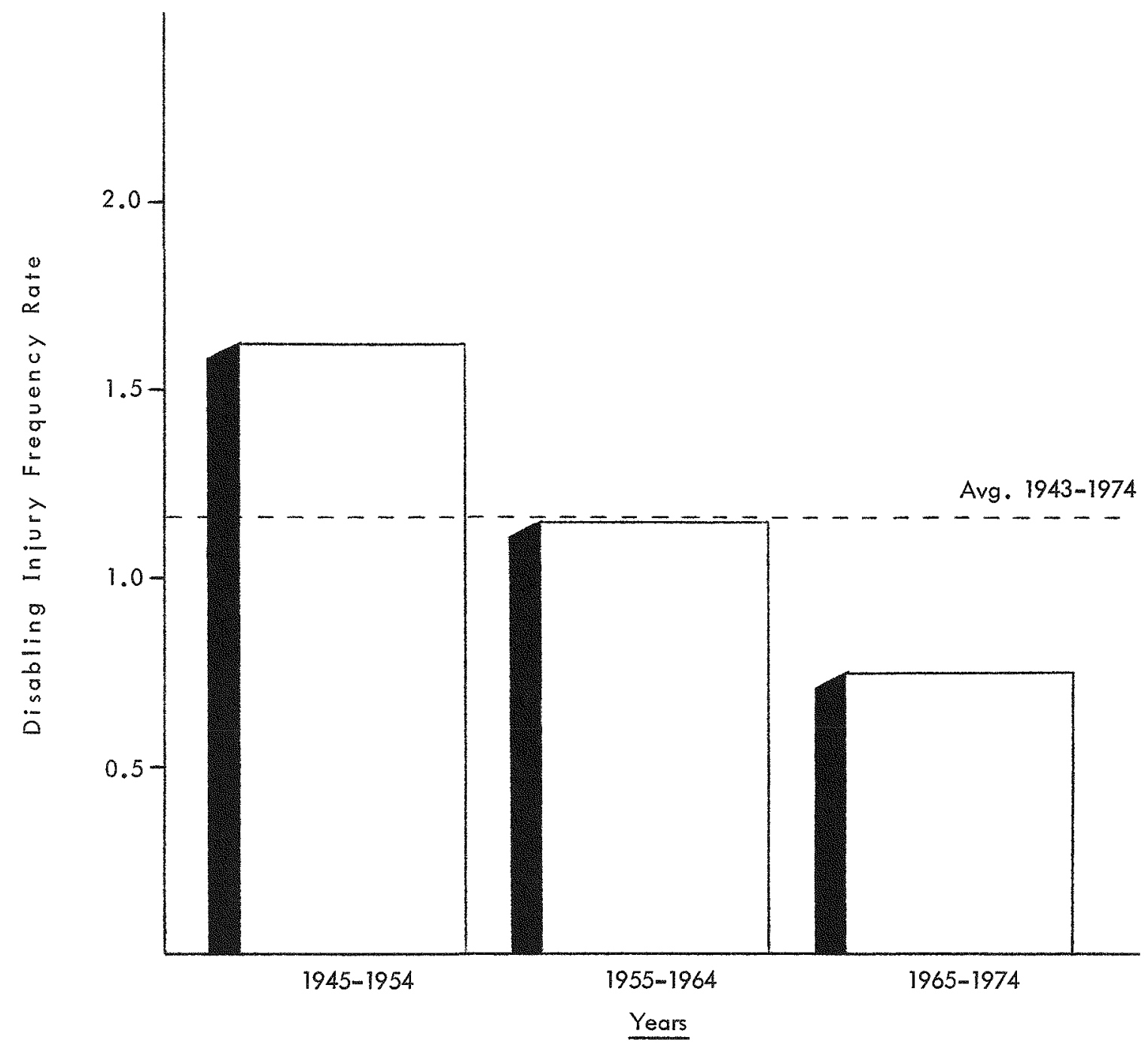

Fig. 6.1.1 ORNL Injury Statistics Averaged by Ten-Year Intervals - (1945-1974) 


\subsection{INFORMATIONAL ACTIVITIES}

\subsection{Visitors and Training Groups}

During 1974 there were about 60 visitors to Applied Health Physics and Safety Sections, as individuals or in groups for training purposes. Included in this number were visitors from South Korea, Bangladesh, and Iran.

\subsection{Publications and Papers}

H. M. Butler, K. M. Wallace, and C.B. Fulmer, "Half-Value Thickness Measurements of Ordinary Concrete for Neutrons from Cyclotron Targets, "AIHA Journal, Vol. 35, No. 4, pp. 234-237, April, 1974.

D. M. Davis, Applied Health Physics and Safety Annual Report for 1973, ORNL4974, August, 1974.

E. D. Gupton, Methods and Procedures for External Radiation Dosimetry at ORNL, ORNL CF-74-10-72, October, 1974.

L. C. Henley and S. R. Bernard, "A Semi-Theoretical Approach to Excretion and Retention of Various Ions," presented at the 20th Bio-Assay, Environmental, and Analytical Chemistry Conference, Cincinnati, Ohio, September 24-25, 1974.

W. F. Ohnesorge and H. M. Butler, "Recent Trends in Particle Accelerator Radiation Safety," presented at the Third Conference on Applications of Small Accelerators, North Texas State University, Denton, Texas, October 20-23, 1974.

W. W. Parkinson, M. J. Kelly (formerly Reactor Chemistry Division), and I. O. Salyer, Monsanto Research Corporation, Dayton, Ohio), "The Effect of Polar Groups on the Post-Irradiation Conductivity of Polystyrene, "Recent Advances in Science and Technology of Materials (edited by A. Bishay), Vol.2, Plenum Publishing Corporation, New York, 1974. 
○

○ 
ORNL-5055

UC -41 - Health and Safety

\section{INTERNAL DISTRIBUTION}

1. Biology Library
2-4. Central Research Library
5. Laboratory Shift Supervisor
6. ORNL - Y-12 Technical Library
Document Reference Section
7-43. Laboratory Records Department
44. Laboratory Records, ORNL R. C.
45. R. G. Affel
46-48. J.A. Auxier
49. J. K. Bair
50. S.P. Baker
51. E.E. Beauchamp
52. N. E. Bolton
53. F.R. Bruce
54. H. M. Butler
55. G. C. Cain
56. R. E. Canning
57. G. T. Chapman
58. C. V. Chester
59-70. R. L. Clark
71. Z. Combs
72. R. A. Crowell
73. F. L. Culler
74-85. D. M. Davis
86. D. G. Doherty
87. R. S. Edwards
88. J. W. Eveleigh
89. L. M. Ferris
90. C. B. Fulmer
9.

91. W. R. Garrett

92. D. C. Gary

93. R.E. Greene

94-99. E . D. Gupton

100. R . F . Hibbs

101. J. A. Holloway

102. J.T. Howe

103. D. G. Jacobs

104. R. G. Jordan

105. M. P. Manning

106. V. A. McKay

107. C. A. Mills

108. J.E. Parham

109. H. Postma

110. J.W. Poston

111. H.E. Reesor

112. C.R. Richmond

113. L. P. Riordan

114. O. A. Rogers

115. J. B. Ruch

116. R.L. . Senn

117. M. H. Shanks

118. B. L . Tidwell

119. A. A. Walls

120-122. A. D. Warden

123. G. R. Wilson

124. R.H. Winget

125. H. A. Wright

\section{EXTERNAL DISTRIBUTION}

126-127. J. A. Lenhard, Director, Research and Technical Support Division, ERDA=ORO.

128-372. Given distribution as shown in TID-4500 under Health and Safety category (25 copies - NTIS). 